IZA DP No. 7666

Money for Nothing? Ukrainian Immigrants in Poland and their Remitting Behaviors

Paweł Kaczmarczyk

October 2013 


\title{
Money for Nothing? \\ Ukrainian Immigrants in Poland and their Remitting Behaviors
}

\author{
Paweł Kaczmarczyk \\ CMR, University of Warsaw \\ and IZA
}

Discussion Paper No. 7666

October 2013

\author{
IZA \\ P.O. Box 7240 \\ 53072 Bonn \\ Germany \\ Phone: +49-228-3894-0 \\ Fax: +49-228-3894-180 \\ E-mail: iza@iza.org
}

\begin{abstract}
Any opinions expressed here are those of the author(s) and not those of IZA. Research published in this series may include views on policy, but the institute itself takes no institutional policy positions. The IZA research network is committed to the IZA Guiding Principles of Research Integrity.

The Institute for the Study of Labor (IZA) in Bonn is a local and virtual international research center and a place of communication between science, politics and business. IZA is an independent nonprofit organization supported by Deutsche Post Foundation. The center is associated with the University of Bonn and offers a stimulating research environment through its international network, workshops and conferences, data service, project support, research visits and doctoral program. IZA engages in (i) original and internationally competitive research in all fields of labor economics, (ii) development of policy concepts, and (iii) dissemination of research results and concepts to the interested public.
\end{abstract}

IZA Discussion Papers often represent preliminary work and are circulated to encourage discussion. Citation of such a paper should account for its provisional character. A revised version may be available directly from the author. 


\title{
ABSTRACT \\ Money for Nothing? Ukrainian Immigrants in Poland and their Remitting Behaviors
}

\begin{abstract}
Analysis of remittances lies in the very centre of the scientific debate on developmental impacts of migration. On the macro level money sent back home may serve as an important source of capital (as compared to the value of export, Development Assistance or Foreign Direct Investment) but also cause inflationary pressure or disincentives for domestic savings. On the micro level remittances may constitute the major source of income and become a means towards consumption smoothing (migration as survival strategy). Notwithstanding, the very nature of remittances and underlying factors are still under theoretical and empirical discussion. The aim of the article is to assess patterns of remittances sent by Ukrainian migrants staying in Poland, to identify the main motives to remit and thus to understand mechanisms governing this process. The article hypothesizes that remitting depends strongly on the structure of migration (including socio-demographic factors responsible for particular motives to remit) and the type of mobility. Particularly, temporary migrants are expected to remit more likely. Econometric analysis based on an unique survey on migration and remittances completed in 2012 shows that in case of temporary migrants whose life centers are still located in sending communities remittances easily become an important part of contractual intra-family arrangements (with altruistic and exchange motives playing also a role). This outcome is important from the policy perspective because it helps to utilize developmental impacts of longstanding temporary migration strategies.
\end{abstract}

JEL Classification: F22, F24, J61

Keywords: remittances, reasons to remit, Ukrainian migrants in Poland

Corresponding author:

Paweł Kaczmarczyk

Centre of Migration Research

University of Warsaw

ul. Banacha 2B

02-097 Warsaw

Poland

E-mail: p.kaczmarczyk@uw.edu.pl

\footnotetext{
* The author wants to thank the CARIM-East project co-funded by the European Commission for the support given to the research leading to this paper.
} 


\title{
Money for Nothing?
}

\section{Ukrainian Immigrants in Poland and their Remitting Behaviors}

\author{
Paweł Kaczmarczyk
}

\section{INTRODUCTION}

Remittances constitute one of the most commonly discussed aspects of international migration. This is mostly due to its (possible) developmental impacts and importance for migrants and their families. At the macro level money sent back home - in 2011 estimated at 479,246 million USD or 0.7 percent of the global GDP (WDI) - may serve as an important source of capital (as compared to the value of export, Development Assistance or Foreign Direct Investment) but also cause inflationary pressure or disincentives for domestic savings. At the micro level (individual / household) remittances may constitute the major source of income and become a means of consumption smoothing. This is particularly well taken in case of temporary migration which commonly becomes a survival strategy for households or whole communities.

Irrespective of the strand of literature looking at impacts of remittances, there is a long debate on factors responsible for remitting and determining the amount sent back home. According to Dustmann and Mestre (2010) understanding of motives lying behind remittances is critical from the policy perspective. Only knowing why remittances are channeled into different purposes it is possible (1) to propose measures increasing the level of remittances and (2) to seek efficient solutions in terms of development.

Mobility of Ukrainian citizens is one the most important recent migration processes in Europe - both in quantitative and qualitative terms. The same refers to remittances. Kupets (2012) points that due to significant increase in the officially recorded value of remittances to Ukraine (assessed as high as 5.6 bln USD in 2010) this issue has become one of the main subjects in recent migration debates in this country. This is why growing bulk of papers look at the developmental impacts of remittances in this and other post-Soviet countries (see Kupets 2012 for overview) but relatively little has been done to understand the very nature and motives lying behind remitting behavior. Moreover, Ukrainian immigrants are critical for Poland being unequivocally the most important migrant group in the country.

Against this background an aim of the article is to assess patterns of remittances sent by Ukrainian migrants staying in Poland, to identify the main determinants of remittances and thus to understand mechanisms governing this process. The article hypothesizes that remitting depends strongly on the structure of migration and the temporal dimension of mobility. Particularly, temporary migrants are expected to remit more likely due to strong ties to their households left behind, contractual arrangements in force and other motives to be discussed in details later. Thus efficient utilization of developmental potential of remittances would imply creating of incentives to support short-term migration strategies.

This paper makes a few important contributions in terms of data and empirics. First, it utilizes an unique data set on Ukrainian migrants in Poland which includes detailed information on migrants, 
their households and remitting behavior. Second, the analytical exercise presented is the very first analysis of remittances of Ukrainian immigrants present in Poland which is striking considering importance of this group for Poland and for Ukraine (with Poland being the second most important destination country). Third, it focuses on temporary migration strategies as shaping significantly remitting behavior which is critical for many less developed economies.

Econometric analysis based on an unique survey on migration and remittances completed in 2012 shows that in case of temporary migrants whose life centers are still located in sending communities remittances easily become an important part of contractual arrangements (with altruistic and exchange motives playing also a role). This outcome is important from the policy perspective because it helps to utilize developmental impacts of longstanding temporary migration strategies.

The article is organized as follows. Section two summarizes theoretical and empirical literature on motivations to remit to build a framework for analysis to follow. Next section presents general picture of Ukrainian migration to Poland, with a special emphasis on remittances sent back home. Section four includes discussion on the data used and empirical strategy applied. Results of empirical analysis are presented and discussed in the section five. Last section concludes.

\section{MOTIVES TO REMIT - A THEORETICAL AND EMPIRICAL OVERVIEW}

The theoretical discussion on the motivations to remit and determinants of remittances was unequivocally started by the seminal papers by Lucas and Stark $(1985,1988)$. The main contribution of both papers is the introduction of an idea to perceive remittances as a part of intra-family contractual self-enforcing arrangement. The point of departure is clear and strongly related to main messages derived from the New Economics of Labor Migration (Stark and Bloom 1985): migrants usually originate from less developed countries (or regions) which are highly prone to risk; migration is then one of the avenues to limit or at least diversify the risks resulting from missing markets or market failures; on the other hand, migration as such can be also risky, particularly in its first phase, and thus the migrant and the family may enter into a "voluntary contractual arrangement". ${ }^{1}$ Lucas and Stark (1985) suggest distinguishing between three main categories of motives: pure altruism (when the migrant derives utility from the utility of those family members left home), pure selfinterest (aspirations to inherit, investments back home) and tempered altruism or enlightened selfinterest. In fact, the latter category encompasses all kind of contractual arrangements between migrants and their families / households (including exchange motives, loan repayment or coinsurance - see also below). This model then served as a point of departure for other scholars suggesting to modify or extend it (Docquier and Rapoport 2009; Dustmann and Mestres 2010; Poirine 1997; Brown and Poirine 2005). Importantly, since mid-1990s the scientific discussion on remittances has been growing in importance, while remittances are commonly being put into the context of extended families or even communities and treated as implicit contractual arrangements $^{2}$. Nevertheless, the main questions remain the same: Who does transfer? For what reasons? Are remitters self-selected? What factors determine the amount of money sent back

\footnotetext{
1 "Remittances may be seen as one component of a longer-term understanding between a migrant and his or her family, an understanding that may involve many aspects including education of the migrant, migration itself, coinsurance, and inheritance" (Lucas and Stark 1988: 458).

${ }^{2}$ This is partially driven by easier access to good quality micro data, in some cases also panel data.
} 
home? etc. Below we summarize the up-to-date discussion on the determinants of remittances to build conceptual framework for the empirical analysis to follow ${ }^{3}$.

The presence of altruistic motivation in remitting behavior can be easily revealed from the Beckerian approach to modeling of human behavior assuming that individuals can derive utility from the consumption of other people, in this case members of the (extended) family. If yes, it can be shown that the optimal level of remittances is given by (Docquier and Rapoport 2009):

$$
T^{*}=\operatorname{Max}\left\{\gamma^{m} I^{m}-\left(1-\gamma^{m}\right) I^{h}, 0\right\}
$$

Where I stands for income, $T$ for the amount remitted from migrant $(m)$ to the household $(h), b$ for the degree of altruism (for migrant and household respectively), and $\gamma^{m}$ is given by:

$$
\gamma^{m}=\frac{\beta^{m}\left(1-\beta^{h}\right)}{1-\beta^{m} \beta^{h}}
$$

Additionally following conditions hold:

$$
\partial T^{*} / \partial I^{m}>0 ; \partial T^{*} / \partial I^{h}<0 ; \partial T^{*} / \partial \beta^{m}>0 ; \partial T^{*} / \partial I^{h}<0 .
$$

According to the model presented it is possible to identify a few variables responsible for remitting behavior. Level of remittances is expected to increase with increase of migrants' income and with decrease of the income of the household left behind - this is the most important implication of the model due to the fact that altruism related variables $\left(\beta^{h}\right.$ and $\left.\beta^{m}\right)$ are not observable ${ }^{4}$. Altruism can be measured by proximity between migrants and their households should increase remittances, similarly as return intentions. Likelihood of remittances as well as the amount remitted does also depend on the number of migrants from a given household (assumed to decrease the level of altruism). Importantly, as suggested by Cox, Esser and Jimenez (1997) there is no clear and linear relationship between income and level of remittances - in fact income may impact the propensity to remit differently depending on the position in their income distribution (or relative income distribution). ${ }^{5}$

The most obvious motivation to remit may be related to self-interest motives. It is likely that people who would like to return will tend to invest at the place of origin and can be more prone to remit (and remit relatively more than those not interested in self-employment upon return). According to many authors (Lucas and Stark 1985; Stark 2009; Docquier and Rapoport 2009) self-interest driven motives can be also derived from the expectations to inherit. In a sense, remittances being sent back home can be treated as a purchase of reputation at home and as a means to increase the inheritance probability. According to this hypothesis higher level of remittances is to be expected in case of those persons coming from relatively wealthier households (e.g. probability of remitting

\footnotetext{
${ }^{3}$ This section draws mainly from an excellent review of theoretical literature on remittances proposed by Docquier and Rapoport 2009 and from Stark 2010.

${ }^{4}$ Docquier and Rapoport (2009) argue that in presence of the altruistic motive the distribution of consumption should be independent of distribution of income (rarely tested in empirical terms).

${ }^{5}$ Brown and Poirine (2005) suggest that we should distinguish between "strong" and "weak" altruism, the latter being more pragmatic and less demanding in terms of sacrificing people's own utility. This model assumes that parents are dominant but benevolent party in the bargaining process. Based on data on remittances to Tonga and Samoa they provide some support for the presence of weak altruism.
} 
increases with income and assets of the household left behind), migrants' income, and the probability of inheriting (strongly correlated with the position in the household). ${ }^{6}$

Risk-sharing behaviors and perception of migration as a risk-diversification device lie in the very center of reasoning started by the New Economics of Labor Migration (Stark and Bloom 1986). Migrants - commonly originating from less developed countries to be described in terms of missing markets or market failures - are expected to become internally or internationally mobile in order to decrease or eliminate the risks faced in country of origin (risk-diversification rationale of migration Stark 2010). Consequently, a large number of motives can be explicitly or implicitly interpret in terms of inter-temporary contractual agreements between migrants and their households (described by Lucas and Stark (1985) in terms of tempered altruism or enlightened self-interest). There are number of options available:

1) Migrants may attempt to maximize the returns to their savings by placing some of it in the country of origin (and by using their families as kind of "intermediaries" and then this form of remittances becomes part of contractual arrangement between the migrant and his/her family) (Stark 2010) - see also point 2.

2) In the presence of significant market failures as well as income volatility which is the salient feature of many less developed countries, migrants may want to insure themselves against bad states of nature. Moreover, it is well possible that both parties involved can act as insurer and insured: in the first period after movement risks related to stay abroad are relatively higher and thus the family is more likely to act as insurer; along with the improvement of labor position of migrants and considering income differences the family will likely become the insured (Lucas and Stark 1988). The terms of the "insurance contract" would then depend on the bargaining power of parties involved. An obvious issue in case of such arrangements relates to factors making it binding. Lucas and Stark $(1985,1988)$ point to mutual altruism, hope for getting bequests as well as direct or indirect control (including role of migrant networks) as the most important self-enforcing mechanisms. Additionally self-enforcement mechanisms can be a part of the migrant nominating scheme and influence selectivity of migration (e.g. depending on the degree of loyalty) (Docquier and Rapoport 2009). According to the theoretical model presented by Docquier and Rapoport (2009) predictions with respect to the migrant's income are similar as in the altruistic model. The insurance model shows, however, that remittances can rise with increase of the recipient's income (among others due to theoretically higher bargaining power), they should be positively correlated with income volatility at origin and should be sent on regular basis (with no decrease over time as expected according to the altruistic model).

Remittances can be interpreted as a means towards consumption smoothing at origin (and are sent in order to avoid income or consumption shocks) (Stark 2010). Moreover, the same argument can be used with regard to migrants themselves and closely corresponds with the insurance motive: migration is a risky process and for this reasons migrants may want to insure themselves. If so remittances can be interpreted as an insurance payment towards future income transfers from the

\footnotetext{
${ }^{6}$ Note that the income of migrants seems to be the critical variable used to differentiate between altruistic and self-interest driven motivations. The situation is even more complicated when we introduce more than two generations setting - in this case remittances sent by children to their parents can be seen as the demonstration effect (with respect to their own children) (Cox and Stark 1994).
} 
family - according to this interpretation migrants more exposed to risks (e.g. undocumented ones) are expected to remit more (Stark 2010; Amuedo-Dorantes and Pozo 2006; Hanson 2006).

Amuedo-Dorantes and Pozo (2006) suggest assessing the insurance motive in a more direct way via linking of remittances to the level of risk in the host country and to self-revealed purposes. In doing so they do not perceive altruism and insurance as competing motives but claim that increase in the risk level should not impact the level of altruism. Authors hypothesize that migrants are risk-averse individuals who respond to the level of risk by insuring themselves in form of remittances. Importantly, they suggest distinguishing between two sub-motives: sort-of purchasing of family provided insurance and self-insurance (precautionary savings) ${ }^{7}$. There are following options available, Figure 1.

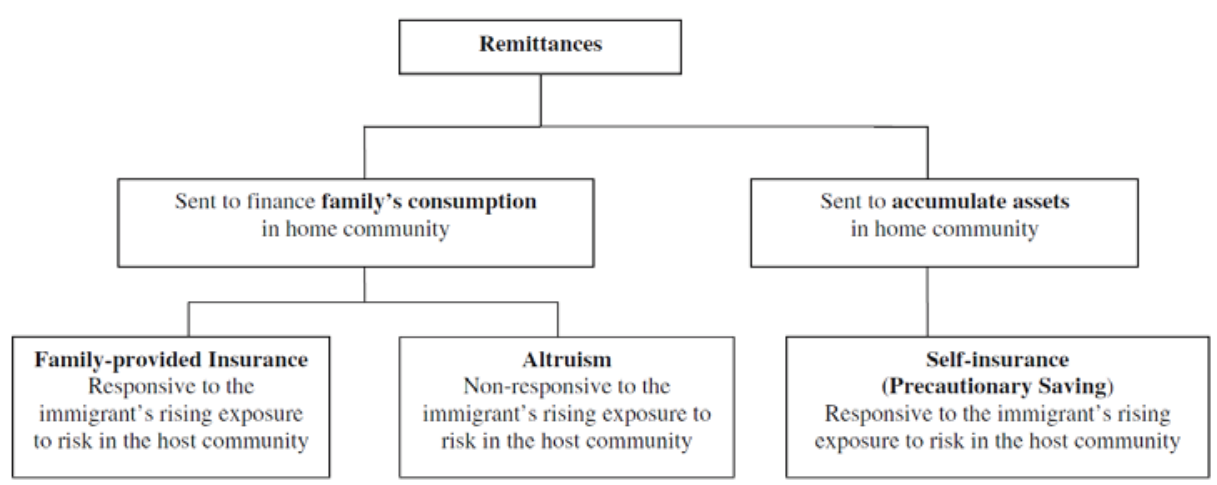

Figure 1. Altruistic and insurance motives for remitting

Source: Amuedo-Dorantes and Pozo 2006: 230.

When remittances are sent for consumption purposes we can claim existence of family-provided insurance if their amount increases with the level of risk in the host country, or altruism in the absence of such link. On the other hand, when remittances are sent to accumulate assets (or savings) and this is combined with increase in risk in the host country, this should be assessed as self-insurance mechanism.

3) Similarly, if migration is an inter-temporal transaction remittances may present a form of loan repayment (e.g. if family helped the migrant in terms of co-financing his/her trip). This is an interesting approach presenting migration as an explicit investment decision: migration is expected to increase the future total income of the household and not as a means towards reducing risks or uncertainty (Docquier and Rapoport 2009). If so, one may expect that this motive should be of more importance for relatively richer families (able to "invest in migration") ${ }^{8}$. In theoretical terms, Docquier and Rapoport (2009) show that if this motive is valid the relationship between recipient's income and amount of remittances would be inverse U-shaped.

This approach can be further extended to include other investments, as for example expenditures related to education. Poirine (1997) presents a two-period, two-person theoretical framework to discuss informal loan arrangements (with "gifted" youth with migration prospects and adults with no education and low productivity as included parties). In such a framework the youth should emigrate (due to higher returns on education) and adults should stay. The main issue remains how to finance

\footnotetext{
${ }^{7}$ This distinction follows from the data on end use of remittances.

${ }^{8}$ But also should increase with the decrease in migration costs.
} 
the education of youth (and not to use the youth labor in place, e.g. on a farm). Poirine (1997) shows that in such a framework borrowing at the market rate makes education (and migration) not a worthwhile business. Instead, informal intra-family loan arrangement can be a solution ${ }^{9}$. From the model presented it follows (among others) that: remittances shall not be used for capital investment; remittances shall have a form of regular "payment" (relatively flat time profile of remittances); the amount of remittances shall depend on the value of "loan" received (e.g. higher for persons with tertiary education) ${ }^{10}$ and also on the expected payback period (higher for relatively older persons). Additionally, according to Poirine (1997) this type of contractual arrangements would result in complex time profile of remittances resulting from inclusion of three waves of migrants: persons paying back their loans, persons who may become a lender (could lend money for education of others) and persons who are expected to return for retirement (and thus making pre-departure investments) - see Figure 2.
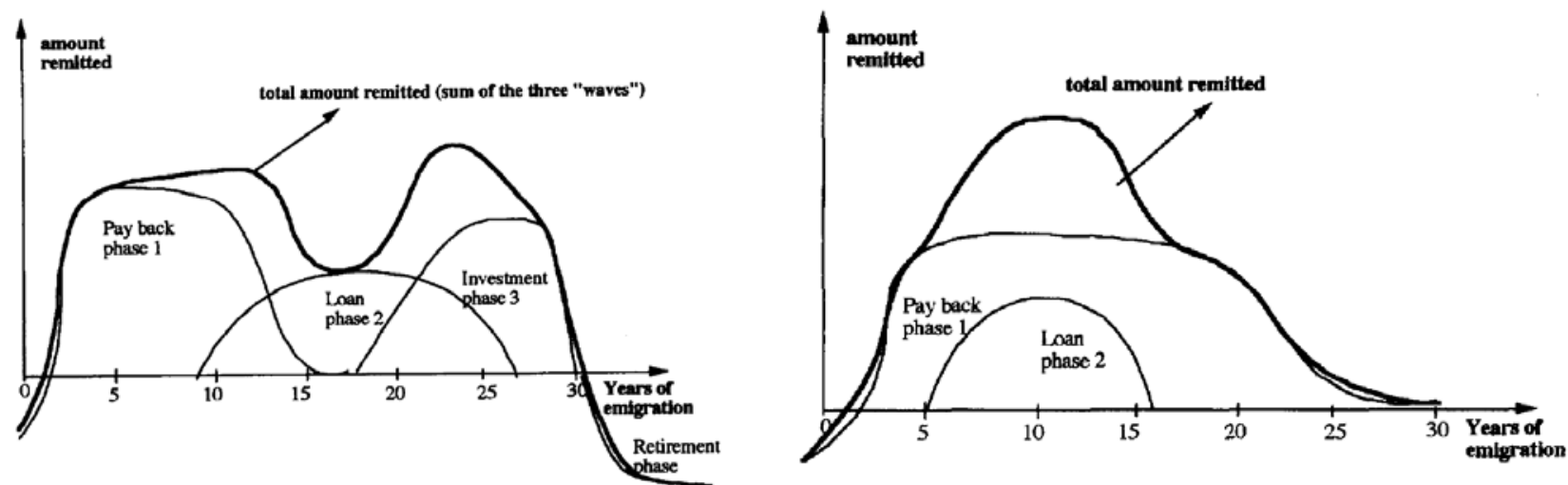

Figure 2. A theoretical time profiles of remittances in the "return case"(left panel) and "no return case"(right panel)

Source: Poirine 1997: 599-600.

4) Next, migrants staying abroad can pay to their households at home for all kind of services provided - in this case we can speak about Pareto-efficient exchanges involving remittances which is particularly advantageous when there is a scope to save transaction (or traditional) costs via nonmarket intra-family arrangements (Rapaport and Docquier 2009). Those exchanges may include care services (child care, elderly care) but also care for assets left home. Importantly, this type of motivation is typically associated with temporary migration strategies. In practical terms, amount remitted is expected to increase with the quantity (and value) of services and with the increase of migrant income (with ambiguous effects related to recipients' income - it can be shown that remittances rise with the increase in the recipients' income) (Rapoport and Docquier 2005, 2009).

In case of contractual interpretation of remittances a lot emphasis was put on the bargaining process and bargaining power of parties involved (Docquier and Rapoport 2009, Stark 2010). One of the proxies to measure bargaining power of migrants and their households left behind is their income position or economic conditions. For example, rise in unemployment is expected to affect

\footnotetext{
${ }^{9}$ Additionally, this approach is further supported by the theory of weak altruism as discussed above (Brown and Poirine 2005).

${ }^{10}$ This argument is, however, empirically difficult to disentangle from the altruistic one, for better educated migrants on average earn more (Lucas and Stark 1985; Docquier and Rapoport 2009).
} 
negatively the bargaining position (of migrant or of the household) ${ }^{11}$. Another option is to look at the origins of migration process and to assess the migrants nominating schemes (Massey et al. 1986). If we assume that structure of migration is conditional on employment prospects at destination, it would also make sense to relate motivation to remit to socio-demographic characteristics of migrants. Stark (2010) emphasizes that migrants may remit because they are forced to do so. In this case presence of strong migrant network could be a good proxy for this particular motive. Moreover, in practical terms one of the most efficient enforcement devices can be the risk of depriving the migrants of their right to inheritance (or even the right to return - Docquier and Rapoport 2009). With respect to the last issue, remittances can be perceived as an investment strategy (from the perspective of the migrant) aimed at securing inheritance - see also self-interest approach above. From the theoretical models it follows that remittances should increase with: value of (home) household's assets (income), probability of inheriting (related to number of household's members), the migrant's income and be ambiguously related to number of migrants in the household (due to competition) (de la Briere et al. 2002; Docquier and Rapoport 2009).

Last but not least, there are theoretical models presenting remitting as a strategic behavior. This approach is close to both NELM (Stark 1995; Stark and Wang 2002) and self-selection model by Borjas (1999). If we assume that employers at destination base their assessment of employability and productivity of migrants on the average data for a given group (i.e. when the individual productivity is not directly / perfectly observable), migrants can be induced to "pay a bribe" to lowskilled persons at origin to keep them immobile (and thus impact positively the average level of productivity and wages) - remittances are to be treated as side-payments being part of "the strategic interaction between migrants and non-migrants"(Docquier and Rapaport 2009: 18) ${ }^{12}$. According to Stark $(1999,2010)$ this motive is very close to self-interest approach for the remittances are meant to protect wages of those staying already abroad. In empirical terms this motive would imply increase in the level of remittances along with the increase in skill level and income of migrants and decline with the recipients' income (Hagen Zanker and Siegel 2007). In practice altruistic and strategic motives are hardly distinguishable, but the presence of strategic motive may be a reason for upward biases in assessment of the altruistic motive (Stark 1999).

In the context of this paper it is important to emphasize the role of temporariness as well as migration strategies including planned return (Cassarino 2004). Dustmann and Mestres (2010) point to the fact that in case of temporary migration schemes remittances sent back home may represent two types of money: pure transfers aimed at supporting (extended) family at origin (e.g. in terms of consumption smoothing) and savings / investments meant to improve migrant's position upon return. Importantly, most of the motives discussed above are related to the first situation. In case of the latter remittances can be presented (and modeled) in a life cycle model. This tendency can be more strengthen by the "intermediaries" motive discussed above, see point 1 ).

\footnotetext{
${ }^{11}$ This is important in empirical terms because unemployment should not impact (directly) the amount remitted according to the altruistic explanation. Docquier and Rapoport (2009) point additionally to importance of information asymmetry which can impact the behaviour of migrants but also household members (moral hazard).

${ }^{12}$ This approach is not fully convincing one. It is possible, for example, that even if members of particular migrant group control the average level of skills, the perception of employers can be based on more general assessment - e.g. assessment of all Polish, Ukrainian or even African workers (Docquier and Rapoport 2009).
} 
Table 1. Theoretical determinants of remittances and their empirical meaning

\begin{tabular}{|c|c|c|c|c|c|c|}
\hline Variables/motives & Altruism & Exchange & Loan repayment & $\begin{array}{l}\text { Self-interest / } \\
\text { investment }\end{array}$ & Insurance & Strategic \\
\hline Migrant's income & $>0$ & $>0$ & $>0$ & $>0$ & & $>0$ \\
\hline Migrant's education & & $>0$ & $>0$ & $>0$ & & $>0$ \\
\hline Time spent at destination & $\leq 0$ & $\begin{array}{l}<0 \text { (typical } \\
\quad \text { for } \\
\text { temporary } \\
\text { migration) }\end{array}$ & $\begin{array}{l}\text { (inverse U-shaped or } \\
\text { flat time-profile) }\end{array}$ & & $\begin{array}{c}\text { (no decrease over } \\
\text { time) }\end{array}$ & $\leq 0$ \\
\hline Distance from family & $\leq 0$ & & & $<0$ & & \\
\hline $\begin{array}{l}\text { Number of migrants (from } \\
\text { the } \mathrm{HH} \text { ) }\end{array}$ & $<0$ & & & $\begin{array}{c}\text { (position in the } \mathrm{HH} \\
\text { matters in case of } \\
\text { inheritance) }\end{array}$ & & \\
\hline Risk level of migration & $\begin{array}{l}\text { (no impact } \\
\text { as a sign of } \\
\text { altruistic } \\
\text { motive) }\end{array}$ & & & & $>0$ & \\
\hline HH income & $\begin{array}{c}<0 \\
\text { (importance } \\
\text { of position } \\
\text { in the } \\
\text { income } \\
\text { distribution) }\end{array}$ & $</>0$ & $\begin{array}{c}>0 \text { (or inverse U- } \\
\text { shaped relationship) }\end{array}$ & (inverse U-shaped) & $\begin{array}{c}<0 \text { (no effect in } \\
\text { the long run; in } \\
\text { case of }>0 \\
\text { enforcement } \\
\text { matters) }\end{array}$ & $<0$ \\
\hline Shocks to $\mathrm{HH}$ income & $>0$ & $</>0$ & & $>0$ & $>0$ & $>0$ \\
\hline $\mathrm{HH}$ assets & & & & $>0$ & $\begin{array}{l}>0 \text { (in terms of } \\
\text { enforcement) }\end{array}$ & \\
\hline Intent to return & $>0$ & & $\begin{array}{c}\text { (impact on the time } \\
\text { profile) }\end{array}$ & & $>0$ & \\
\hline
\end{tabular}

Source: Own elaboration based on Hagen Zanker and Siegel 2007: 5; Docquier and Rapoport 2009: 39.

Table 1 summarizes most of the expectations concerning the models and related factors (variables) as derived from theoretical models at hand. The problem is that remitting may involve many (all?) above discussed motives at the same time and it could be difficult to disentangle them (which remains thus an empirical question). In the rest of this section we summarize the most important empirical findings and focus on particular characteristics of migrants and migration. ${ }^{13}$ While reviewing the empirical literature we will depart from a large number of papers on impact of remittances (Stark 1980; Adams 1991; Hoddinott 1994; Massey and Parrado 1994; Taylor 1999; Catrinescu et al. 2006; de Haas 2007; Adams 2011; Ullah 2011) and focus predominantly on the motivations to remit, critical to understand mechanisms towards remittances and to plan possible political measures ${ }^{14}$.

A large number of papers look at the individual characteristics of migrants and household structure and their impacts on likelihood and amount of money remitted. In a classical paper Banerjee (1984) assesses factors responsible for remitting and amount of money transferred from Delhi. Additionally, he compares the results to outcomes provided by Knowles and Anker (1981) for Kenya - to our knowledge the first scholars who suggested to model separately the decision to migrate and level of

\footnotetext{
${ }^{13}$ For an extensive review of empirical literature devoted to particular theoretical motives see Docquier and Rapoport 2009.

${ }^{14}$ Additionally we will focus (almost) exclusively on the micro studies on the motivations to remit which is consistent with empirical analysis presented in the later part of the article.
} 
remittances. His analysis highlights the importance of personal variables (income, education), family related variables (e.g. marital status, presence of partner in the country of immigration) or those showing strong attachment to country of origin (e.g. land possessed). Moreover, significant differences between two issues analyzed are shown (decision to remit and level of remittances). Lucas and Stark $(1985 ; 1988)$ provide evidence from Botswana supporting presented by them theoretical hypotheses on motives to remit: investments in education as a part of contractual arrangements within family, remittances driven by a strategy to secure inheritance, and remittances as risk diversification mechanism at the family level ${ }^{15}$. Hoddinott (1994) looks both at the propensity to migrate and to remit in case of migrants from Kenya. He shows that remittances are to be considered as a part of inter-temporary arrangements within families including chances to be bequested.

Funkhouser (1995) uses household level data from El Salvador and Nicaragua to assess the determinants of remittances to these two countries (and particularly: differences in remitting behavior, i.e. significantly higher share of remitting migrants in case of El Salvador). Author relates differences observed to selection patterns both in case of migration process and remitting process (out of migrants' pool). Thus he suggests clearly distinguishing between fact of remitting and level of remittances because they are supposed to result from different set of factors. Models estimated prove most of the standard expectations to be derived from above presented models but with an emphasis on the factors responsible for self-selection.

De la Briere et al. (2002) test the self-insurance versus investment hypothesis with regard to Dominican internal and international migrants. They show that the insurance function is strongly related to gender with female migrants in the US supposed to "pay" insurance fee to their parents staying in Dominica while male migrants acting as insurers. There is no impact of gender noted on the investment. Generally, outcomes presented show that motives to remit may depend strongly on gender, position in a household and migrants' nominating schemes. These outcomes are closely related to those presented by Hoddinott (1992) who shows that remittance behavior of sons and daughters are different in statistical terms (and male migrants respond more to parents' inheritable assets). These results are strongly supported by Rahman and Kwen Fee (2012) who point to importance of gendered aspects of remittances (as well as the broad issues related to the social and not purely monetary contexts of the process). In a paper based on the MMP and LAMP data sets Sana and Massey (2005) provide arguments that remittances may be closely related to patriarchal traditional family structures and migrant nominating schemes. The general effect can be, however, conditional on opportunities at origin which is shown by significant differences between remitting behavior of Mexican and Dominican migrants (see also below).

Agarwal and Horowitz (2002) base their analysis on simple theoretical model (with emphasis on intra-household relations and presence of multiple migrants) and test altruistic vs. risk sharing motives in the case of remittances to Guyana. Based on differences between remitting behavior of single and multiple migrants they conclude about importance of the altruistic motives to remit. Empirical support for altruistic motives behind remittances is also provided by Okonkwo Osili (2007) in case of Nigerian migrants. In case of Germany, Holst and Schrooten (2006) report significant impact of such factors as age, gender, marital status on the probability and level of remittances.

\footnotetext{
${ }^{15}$ They also show a positive impact of income on remittances which is related to many of motives discussed before.
} 
The role of gender is commonly discussed and emphasized. In a classical paper Lauby and Stark (1988) look at migration patterns in case of Philippines and point to clearly identifiable migrant nominating schemes involving young females as a consequence of pull forces in the major host countries (with important effects for remittances). Holst et al. (2012) study determinants of remittances from Germany to find that income difference are not capable to explain gender differences in amount of money remitted. Network effects or life cycle variables (particularly marital status) are instead much better in terms of explanatory power. Additionally, citizenship acquisition is found to change the importance of gender related variables. This kind of observations are also commonly supported by qualitative studies showing significant role of gender relations as shaping remitting behavior (Vullnetari and King 2011).

There is a long-standing discussion on the impacts of education (or skill level) on the remitting patterns. Level of skills can influence the level of earnings but also process of integration (and settlement). This is one of the reasons why the literature provides rather mixed results on that issue. Niimi et al. (2006) position the issue of remittances in the broad context of brain drain debate and argue that contrary to expectations (possible) negative effect related to outflow of well skilled persons can be hardly offset by remittances sent back to country of origin. Based on macro data (regional aggregates) they show that remittances decrease with the share of the well-educated migrants. Similar expectations have been presented by Faini (2007). This outcome has been challenged by Bollard et al. (2009) who refer to micro data (from eleven important migrants receiving countries). They claim that level of education has an unequivocal impact on the propensity to remit but strong positive impact on the amount remitted (mostly as a by-product of higher level of income, on average). Dustmann and Mestres (2010) claim that better educated persons are ceteris paribus less likely to remit due to the fact that are less affected by family or social pressure to remit. Last but not least, Docquier et al. (2011) discuss the responsiveness of remittances to education level in the presence of diverse types of immigration policy (precisely: difference in remitting behavior between highly-skilled and low-skilled immigrants). Importantly, they show that the relationship between education and remittances is not unequivocal and largely depend on the migration policies (what could explain controversies presented above). According to the theoretical model provided remittances are expected to be positively correlated with education in the presence of more restrictive and less selective (with regard to skills) immigration policy (the second part of the model is hardly intuitive...). These expectations are proven by empirical analysis based on bilateral remittances data (aggregate level data). Nikos and Baklavas (2009) assess the importance of individual characteristics for remitting behavior of Albanian immigrants (one of the most important European processes in terms of remittances) to find that there are statistically significant differences between people belong to two groups: relatively well educated migrants with high employment chances (and relatively high incomes) and those poorly educated often with unstable jobs and bad labor market prospects (on a basis of cluster analysis).

Next important strand of literature relates to the role of opportunity structure in remitting process. Brown (1997) assesses the importance of motivations' related factors in the context of long-term development perspectives of the Pacific islands and concludes that migrants are driven by a broad set of factors beyond pure altruism including investments or asset accumulation at origin. Hovolli (2009) explicitly points to role of business environment at origin and its perception as one of the main factors responsible for remitting patterns, particularly those driven by investment reasons (along with traditional variables as duration of stay). 
Amuedo-Dorantes and Pozo (2006) argue that income volatility is one of the major concerns in many less developed countries and if yes, theoretically remittances may be understood as a means towards income smoothing and thus limiting above mentioned volatility. They inquiry the Mexican data on households' income and expenditures to find that remittances significantly reduce income volatility of migrant households.

Arun and Ulku (2010) show that in case of Asian communities in Birmingham (Indian, Pakistani and Bangladeshi) there is a difference between motives to remit depending on the purpose of migration and remittances as such. In general terms motivations to remit can be associated to most of typically considered variables (income, gender, age, duration of residence, linkages to the home country etc.) but the level of remittances is strongly dependent on the purpose with money sent for consumption purposes being significantly lower than for investment purposes. This kind of relationship was also claimed with regard to Polish migrants (Kaczmarczyk 2005). Interestingly, no difference was found between temporary and permanent migrants (Arun and Ulku 2010). Liang at al. (2013) assess migration patterns of internal migrants in China and point to the importance of household position in the sending region. Generally, they claim that those migrants who come from more "entrepreneurial" households tend also to remit more. This effect may be also related to particular "culture of remittances". This outcome is clearly in line with Sana and Massey (2005).

Many papers report positive relationship between remitting (likelihood, in some cases also level) and legal status (as a proxy of the risk level). Specifically illegal migrants are expected to remit more which is in line with the insurance hypothesis (Amuedo-Dorantes and Pozo 2006; Holst and Schrooten 2006; Piracha and Zhu 2012; Collier et al. 2011). Amuedo-Dorantes and Pozo (2012) depart from the NELM assuming migrants to take advantages of being present in diverse economic settings and thus being able to diversify risks faced. However, they address very interesting issue: in case of risks born by emigrants' households we can assume that remittances will be used as a means of consumption smoothing; in case of migrants themselves assets diversification may plan similar role (in terms of risk diversification) and, moreover, migrant networks may play an important role in the process of asset holding. Based on the recent Spanish data they show that immigrants respond to a set of portfolio variables (real depreciation of the home currency, volatility of the real exchange rate, interest rates and GDP growth in countries considered). This feature is persistent irrespective of education level but depends on the country of origin (which may suggest importance of diverse motives for emigrating and remitting).

In context of this paper type of migration is one of the most critical issues. In one of the most influential papers on that issue Dustmann and Mestres (2010) claim that propensity to remit (and amount remitted) is expected to be higher in case of temporary migrants because their life centers are still located in countries of origin (and the residential locations of their families are there) (similar outcomes are presented by Merkle and Zimmermann (1992) who stress that according to the life cycle hypothesis temporary migrants should have remit more because they do expect that they future income will be lower than the recent income). Dustman and Mestres (2010) emphasize that in case of temporary migrants traditionally discussed remitting motives are somehow mixed: sending money back home may be treated as a manifestation of family support (or pure altruistic behavior) but also as simple savings or investment for future consumption at home ${ }^{16}$. This argument is strongly

\footnotetext{
${ }^{16}$ Dustmann and Mestres (2010) argue that in case of temporary migrants remittances can be easily interpreted in terms of inter-temporal allocation of consumption.
} 
supported also by the insurance motive and investment motive presented in the previous section. With regard to the last point Amuedo-Dorantes and Pozo (2012) show that, immigrants responsiveness to portfolio variables increases with the length of their migration which may suggest that more settled migrants diverse more their financial assets. Holst and Schrooten (2006) with regard to immigrants staying in Germany claim that plans or pressure to return impact significantly remitting behavior (as found in case of Turkish migrants and people from former Yugoslavia). Collier et al. (2011) refer to migration from three North African countries (Algeria, Morocco and Tunisia) and assess relationship between remitting behavior (likelihood and amount remitted) considering conditions before migration and during stay abroad (with particular emphasis on the return plans). Except for showing a close link between set of migrants' characteristics and remittances (education, labor market status, time spent abroad, legal status) they point to the importance of return plans. Particularly those migrants who already decided to return are expected to remit more and spend the money to larger extent on investment purposes. Collier et al. (2011) emphasize that in case of those persons who are not planning to settle abroad level of remittances can increase along with the time spent abroad. This is due to the fact that most of the theoretical arguments discussed before are still in force and at the same time they are able to remit more due to labor market absorption in country of immigration.

Several empirical models point to (possible) importance of migrant networks. In a paper looking at Ghanaian immigrants in the Netherlands Mazzucato (2009) asks a question whether geographical proximity is a precondition for informal insurance arrangements. She finds that (1) there is a risk pooling mechanism based on remittances and reverse remittances and that (2) migrant networks may play important role in this process (mostly through monitoring and enforcement). Aparicio (2011) adds network effects into the analysis of remittances and based on the Spanish database claims that more networked migrants tend to remit more, particularly when they do belong to high remitting country group. This contradicts expectations by Amuedo-Dorantes and Pozo (2006) who assign important role to insurance motive expected to decrease with the presence of strong networks but is in line with other papers suggesting to look at migrant networks as a part of reinforcement mechanism (Piracha and Saraogi 2011).

Last but not least, several papers assess the importance of political factors and changes in migration policies. Soltero (2009) tests hypotheses drawn from the NELM in case of Mexican born immigrants staying in Illinois. Interestingly, most of the significant variables refer to life cycle of immigrants (marital status, gender, position in the household, presence of children) and not to human capital (education, level of income, work status). There is also a clear negative relationship between American citizenship and propensity to remit. Mahuteau et al. (2010) refer to the change in Australian entry policy as a "natural experiment" to assess the remittance behavior of two cohorts: those who entered the country before and after legislative changes. Results provided show that process of migrants' selection has indeed an impact on the remitting. Particularly, those migrants who arrived under more strict entry conditions are less prone to remit but if they do amount of their remittances is generally higher. This is one of the studies proving an importance of distinction between decision and level model. Note also important contribution by Docquier et al. (2011) on relationship between selectivity by education and migration policies.

Against this background the evidence from Central and Eastern Europe is rather limited. This is unfortunate because this region is particularly important and interesting due to the predominance 
of temporary forms of migration and common patterns of long-standing circular mobility. Markova and Reilly (2007) assess the factors shaping remitting behavior of Bulgarian migrants in Madrid region and find that level of remittances is to be linked to set of socio-demographics (gender, marital status, number of household members in Bulgaria and abroad), labor market status (income) but predominantly to the legal status of a given migrant - with illegal migrants sending considerably more. Siegel (2010) assesses factors responsible for choosing of particular transfer channels by Moldovan migrants and point to importance of gender related migration and work patterns. In case of Moldova, Piracha and Saraogi (2011) find empirical arguments to support both altruistic and investment motives to remit. In practical terms, it means that both individual and household variables (gender, income status, age, presence of children and other migrants, migration plans) as well as community level factors impact remitting behavior of Moldavians. Krzesicki (2012) assesses the remittances of Polish migrants sent in the post-enlargement period from the UK and Ireland (2007-2009) and concludes that outcomes of empirical analysis - particularly presence of strong effects related to family characteristics - point to both altruistic as well as inter-family arrangements motives. Last but not least, Strielkowski et al. (2012) examine importance of diverse characteristics for remitting behavior of Ukrainian immigrants in the Czech Republic. They find that they are significant differences between factors responsible for decision to remit and amount remitted. In the first case the most important explanatory factors include socio-demographics (age, gender, household size) and the family level of income, in the former the critical regressor is the migrant's income. Several recent research reports look at the remittances in the post-Soviet space but primarily assess their impacts on receiving economies (Stratan et al. 2013 for Moldova, Karapetyan and Harutyunyan 2013 for Armenia, and Kupets 2012 for Ukraine). Kupets (2012) refers to Ukrainian micro data set (Modular Migration Survey) to show that wast majority of Ukrainian migrants support their families back home (through remittances or in-kind support). Her analysis shows difference between remitting behavior of the short-term and long-term migrants with favor to the former category. Legal status does not have a significant impact on propensity to remit. Generally, higher probability of sending remittances should be attributed to males, married persons aged 35 and more with secondary levels of education, and coming from rural areas, particularly from Western part of Ukraine.

\section{UKRAINIAN IMMIGRANTS IN POLAND AND THEIR REMITTANCES}

Poland is one of the traditional emigration countries and (still) a net emigration area. This is due to two factors: very high intensity of international mobility of Poles and relatively low level of incoming flows. Polish citizens have migrated on massive scale since mid-19 century. Intensity of these flows increased in the 1980s and then after the EU-enlargement when the relative share of migrants in the population reached 6-7 percent (Kaczmarczyk 2010). Notwithstanding, beginning of transition period saw also increase in scale of immigration to Poland - previously to be considered as (almost) closed country. Poland has hosted all possible categories of immigrants: from asylum seekers and refugees, highly skilled expatriates, labor migrants, seasonal workers to family members. Nevertheless, the scale of immigration is still remarkably low, particularly as compared to the size of out-migration. Recently published data from the 2011 National Census shows 55.4 thousand persons without Polish citizenship staying permanently in Poland ( 0.1 percent of the total population). The number of temporary migrants (staying in Poland for over 3 months) was assessed at 56.3 thousand. Other 
sources provide similar numbers. According to the Central Population Register, in the period 20012011 around 113 thousand persons registered in Poland for a permanent stay. However, number of those registered for temporary stay in 2011 was as high as 66 thousand. Labour Force Survey reveals around 40-45 thousand of foreigners aged 15 years or more staying in Poland in 2011 (Fihel et al. 2012).

The data shows Poland as increasingly emigration-immigration country although the transition from migrant sending to migrant receiving area has not been completed so far. However, according to many observers this seems to be inevitable process. In a sense Poland follows in the wake of Northern and Western European and later Southern European countries. According to the concept of migration cycle this transition is closely related to both demographic and economic factors (Okólski 2012). Recent massive emigration seriously distorted the process but there are signs of slow changes with respect to immigration (see below). Moreover, even if "traditional", settlement migration to Poland is low or very low, temporary migration is growing in importance. This is the case particularly since 2007 when a new simplified procedure was introduced to allow persons from Eastern Partnership countries to work in Poland without permit for up to 6 months a year. Since then number of documents issued (employers' declarations of intent to employ a foreigner) grew to around 250 thousand annually (as compared to around 40 thousand individual work permits issued in 2011 and 2012). Altogether, the number of declarations issued between 2007 and 2012 was as high as one million showing a significant potential demand for foreign labor as well as migration pressure from the Eastern Partnership countries (Fihel et al. 2012; Duszczyk et al. 2013). In terms of origin, immigrants to Poland come from only a few regions (countries): particularly from the postSoviet space (mainly from Ukraine) and Vietnam. Recently, the number of incoming Chinese or Nepalese migrants started to rise dynamically. Migrants to Poland are very strongly concentrated in large towns and urban areas. Warsaw area is definitely the most attractive one, hosting majority of all immigrants irrespective their category or country of origin ${ }^{17}$ (Fihel 2007; Górny and TorunczykRuiz 2011).

Ukrainians are the single most important migration group in the country. This migration started in late 1980s when citizens of post-Soviet states commonly used circular migration strategies to gain from cross-border trade or short-term employment in Poland (Górny et al. 2010). Recently, Ukrainians dominate in most of categories of entry and stay (except for refugees and asylum seekers). In 2011, Ukrainians constituted 24 percent of foreigners identified by the National Census (17 percent in case of those staying temporarily), 28 percent of foreigners registered for temporary stay, 52 percent of working permit holders and, most importantly from the short-term perspective, over 92 percent of persons coming to Poland on the basis of the simplified procedure (based on CSO and Ministry of Labour Data). The large majority of Ukrainian migrants to Poland are those working or settled in the Mazowieckie region (Gorny and Torunczyk-Ruiz 2011; Górny et al. 2010; Fihel et al. 2007). This is one the reasons why most of the large scale studies were focused on this particular area. The small number of methodologically acceptable studies of migrants to Poland is due to the lack of official data (e.g. very low samples of immigrants in data sets like LFS or EU-SILC) and lack of sample frame. Only recently two studies have been completed which used the Respondent Driven Sampling as the main method of sample selection - see next section for methodological details

\footnotetext{
${ }^{17}$ According to the 2011 National Census over 30 percent of all immigrants in Poland were residing in Mazowieckie region (and particularly in Warsaw area).
} 
(Górny and Torunczyk-Ruiz 2011; Napierala and Górny 2011). Further we focus on outcomes of one of these studies while discussing structural characteristics of Ukrainian migrants to Poland (or precisely: in Warsaw area $)^{18}$. Table 2 includes selected characteristics of the sample under consideration.

Table 2. Descriptive statistics of the sample

\begin{tabular}{|c|c|c|c|c|}
\hline \multirow[b]{2}{*}{ Characteristics } & $\begin{array}{c}\text { No. of observation } \\
\text { / Average }+\end{array}$ & $\begin{array}{c}\text { Percentage / Std. } \\
\text { dev. }+\end{array}$ & $\begin{array}{c}\text { No. of observation } \\
\text { / Average }+\end{array}$ & $\begin{array}{c}\text { Percentage / Std. } \\
\text { dev. }+\end{array}$ \\
\hline & \multicolumn{2}{|c|}{ Males } & \multicolumn{2}{|c|}{ Females } \\
\hline \multicolumn{5}{|c|}{ Age } \\
\hline Average age $t$ & 35.01 & 9.907 & 39.56 & 10.992 \\
\hline Percentage aged 21-45 & 145 & 0.784 & 174 & 0.613 \\
\hline Percentage aged $46-60$ & 32 & 0.173 & 96 & 0.338 \\
\hline Percentage aged over 61 & 0 & 0.000 & 4 & 0.014 \\
\hline \multicolumn{5}{|c|}{ Family status } \\
\hline \multicolumn{5}{|l|}{ Marital status } \\
\hline Single & 62 & 0.335 & 70 & 0.246 \\
\hline Informal relationship & 5 & 0.027 & 10 & 0.035 \\
\hline Married & 90 & 0.486 & 106 & 0.373 \\
\hline Divorced/separated & 25 & 0.135 & 71 & 0.250 \\
\hline $\begin{array}{l}\text { Widowed } \\
\text { Percentage of households with }\end{array}$ & 3 & 0.016 & 27 & 0.095 \\
\hline dependants & 13 & 0.070 & 35 & 0.123 \\
\hline \multicolumn{5}{|c|}{ Education } \\
\hline \multicolumn{5}{|l|}{ Level of education } \\
\hline Primary & 6 & 0.032 & 10 & 0.035 \\
\hline Secondary & 103 & 0.557 & 158 & 0.556 \\
\hline post-secondary and tertiary & 76 & 0.411 & 116 & 0.408 \\
\hline \multicolumn{5}{|c|}{ Migration history } \\
\hline \multicolumn{5}{|l|}{ Year of first migration to Poland } \\
\hline before 1990 & 0 & 0.000 & 2 & 0.007 \\
\hline $1990-2003$ & 30 & 0.162 & 87 & 0.306 \\
\hline 2004-2008 & 36 & 0.195 & 66 & 0.232 \\
\hline $2009-2012$ & 119 & 0.643 & 129 & 0.454 \\
\hline Average no. of migrations + & 2.946 & 2.136 & 4.486 & 2.932 \\
\hline \multicolumn{5}{|c|}{ Labour market status } \\
\hline Labor market status - employed & 168 & 0.908 & 270 & 0.951 \\
\hline Labor market status - unemployed & 15 & 0.081 & 12 & 0.042 \\
\hline Wage-employment (last week) & 164 & 0.886 & 260 & 0.915 \\
\hline Average net monthly income & 2762.546 & 1885.493 & 2072.293 & 834.496 \\
\hline Legal status - illegal job + & 38 & 0.250 & 56 & 0.197 \\
\hline $\mathbf{N}$ & 185 & 1.000 & 284 & 1.000 \\
\hline
\end{tabular}

Source: Own elaboration based on the RDS/CMR/2012 data base.

From the above presented data it follows that immigrants in the sample are relatively young and this is typical feature of most mobile persons ( 78 percent of males and 61 percent of females of mobile age). However, the average age is higher than it could be expected and it refers predominantly to women - around 35 percent of females in the sample constitute persons aged over 46 years. This is

\footnotetext{
${ }^{18}$ Data courtesy of National Bank of Poland and Centre of Migration Research Foundation.
} 
also clearly visible when analyzing the age distribution of immigrants from Ukraine: there is an obvious bias towards older age groups in case of women with significant shares of mobile women in their 40s and 50s. This is one of the most prominent features or recent migration from Ukraine to countries like Poland or Italy where job offers are most plentiful in home and care sectors. The age distribution is but also function of push factors - poor labor market conditions and family situation of older women. According to the survey data, while in case of men single and married individuals dominate, in case of women around 35 percent constitute divorced and widowed persons. This reflects the specific migration strategy applied by Ukrainian women. Their migration histories are also much longer. In general, majority of migrants in the sample started to migrate to Poland only recently: 85 percent of males and 69 percent of females arrived to Poland for the first time (for nontouristic purposes) after the EU-enlargement. However, around 31 percent of female migrants started their mobility paths before $2003^{19}$.

Life of Ukrainian migrants in Poland - at least those captured by the survey - is still largely oriented towards country of origin, which is of critical importance for analysis to follow. Most of the migrants apply temporary migration strategies. Only small fraction of both men and women report to have dependants present in Poland. Ukrainian migrants are relatively well educated with majority of persons having at least secondary education. This does not necessarily translate into higher level of income. Ukrainian men earn slightly more than Ukrainian women but there is only minor correlation between level of education and earnings. This is to be attributed to the fact that majority of Ukrainian migrants to Poland can be classified as working in the secondary sectors (such as construction, agriculture and household services).

The assessment of importance of remittances for Ukrainian society and economy is conditional on two issues: scale of migration and the size of the economy. Figure 3 shows the scale of remittances sent to Ukraine in absolute and relative terms (as a share of GDP).

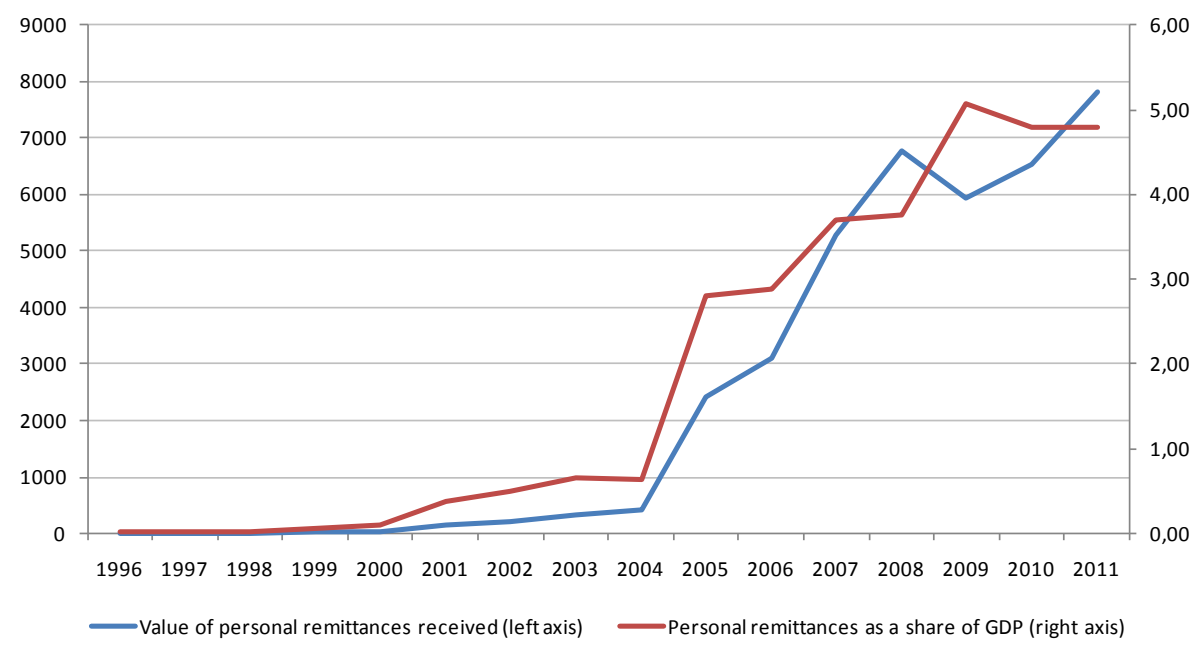

Figure 3. Value of remittances sent to Ukraine (in million of USD) and their share in the GDP (\%, right axis) Source: Own elaboration based on the World Development Indicators.

As compared to other post-Soviet countries, in case of Ukraine remittances constitute relatively low fraction of GDP - in 2010 around 5.6 billion USD amounted to 4.1 percent of Ukrainian GDP (as

${ }^{19}$ Average number of stays in Poland is also much higher in case of female migrants. 
compared to 11 percent in Armenia, 28 percent in Kyrgyz Republic and 24 percent in Moldova) (according to the Ukrainian data which presents slightly smaller figures than the WB data). Notwithstanding, macroeconomic effect of remittances should not be underestimated - in 2010 remittances constituted 86 percent of total FDI net inflows, 840 percent of official development assistance and 51 percent of current account balance. Moreover, money remitted can represent up to 65 percent of the total household income, depending on its wealth level (Kupets 2012). Importantly, since 2004 there is a strong increase in value of remittances observable ${ }^{20}$.

In the context of this paper there are several important issues related to remittances sent to Ukraine. First, remittance data are not fully reliable. Kupets (2012) claims that official data severely underestimate the real flows whereas estimates available are not reliable neither (they vary from 7 to 54 billion USD!). For obvious reasons official data fail to recognize the transfers through informal channels (including social networks) - this is why according to official data the most important sending countries include both important host countries (Russia) as well as rather marginal ones (Cyprus, Switzerland, Singapore, Panama). This is why reference to micro data on remittances is so important. Second, micro data on migration (Modular Migration Survey) reveals large differences in terms of migration patterns between regions of origin (with Western part of Ukraine as receiving the most remittances) and countries of destination. For example, share of Ukrainian migrants who sent remittances from Poland was as high as 45.9 percent as compared to 79 from Italy and 82 percent from Spain. This feature may be conditional on migration strategies applied. Third, there are clearly visible remitting patterns with regard to socio-demographic characteristics - generally, married males at age 35-59 coming from rural areas who also completed secondary education remit the most often. Fourth, there is a clear link visible between type of migration (with those staying abroad for more than 12 months remitting more) while impact of the legal status is negligible (Kupets 2012).

The body of research on immigration to Poland, including Ukrainian immigrants, is growing but the papers on economic aspects of the inflow are scarce. This refers particularly to economic features of migration. To our knowledge it is the very first study looking at remitting behavior of Ukrainian immigrants present in Poland.

\section{DATA AND EMPIRICAL STRATEGY}

The analysis presented in sections to follow will be based predominantly on a unique data set on Ukrainian migrants in Poland. As clearly indicated in the previous section there exists neither comprehensive nor reliable official data on immigration to Poland. Official register data portrays only (small) fraction of the phenomena, additionally they are not accessible as individual data and as a general rule do not include detailed enough information on migrants' remittances.

For above reasons the only reasonable empirical strategy is to refer to data stemming from dedicated surveys. In this paper we will refer to a unique survey completed in Warsaw area in second half of 2012. Immigrant populations are commonly referred to as rare, "hidden", or hard to reach. In case of such populations conventional sampling designs would produce potentially biased samples. Thus, one of the research strategies applied for analysis of this kind of populations is to use auxiliary information during the research. These procedures are called "adaptive sampling

\footnotetext{
${ }^{20}$ Note, however, that this change can be well attributed to changes in methodology of collecting data on remittances - see Kupets 2012.
} 
strategies" and are based on the idea that the procedure for inclusion of subsequent units in the sample depends on values of particular variables. In case of receiving country one of the most promising strategy is to refer to Respondent Driven Sampling which uses extensive information on migrant networks as a basis for estimation of sample characteristics and its representativeness ${ }^{21}$ (Seber and Thompson 1996; Turk and Borkowski 2005; Heckathorn 1997). Data collected include comprehensive information on around 500 Ukrainian immigrants, including their detailed migration trajectories, family situation (in Poland and Ukraine), labor market participation, remittances, social benefits claimed and migrant networks. Survey data was collected on individual basis but a set of household level data is available. Three important features of the survey are necessary to comment on. First, survey encompassed exclusively Warsaw area and thus data presented are not representative at country level. Notwithstanding, due to structural characteristics of Ukrainian immigration and strong concentration of immigrants in Warsaw they can be used as a proxy of the general situation of Ukrainians in Poland. Second, in Polish case RDS proved to be very efficient in capturing all kind of immigrants, including settlement migrants, temporary workers and even students, legal and illegal ones (Górny and Torunczyk-Ruiz 2011). To our knowledge it is the only such comprehensive and methodologically reliable source of data to be used for analyses of immigrants' situation in Poland. Third, full analysis of motivations to remit would encompass situation of migrants and households left behind. In practice, data on migrants are being used (with much less information on migrants' households) or data on remittance receiving households (with limited information on migrants themselves). In this paper we focus predominantly on migrants.

Most of the empirical literature dealing with micro-data focuses on disentangling particular motives responsible for decision to remit (or determinants of remitting behavior) and value of remittances and this is the approach we will follow here. The main problem lies in distinguishing between motives to remit discussed in the previous section, as theoretical models do not provide unambiguous way of doing that (particularly to distinguish altruism from other motives - Hagen Zanker and Siegel 2007).

In purely empirical terms early papers on the remitting behavior applied traditional OLS methodologies (Lucas and Stark 1985, 1988). In case of remittances the main problem, however, lies in the censoring of the dependent variable, i.e. only part of migrants do remit and thus including all of them in the analysis of level of remittances would produce biased results (Banerjee 1984; Hoddinott 1994; Collier et al. 2011). In the literature zero value of remittances is treated as behavioral zero or random zero. In the former case, zero is an outcome of migrant conscious choice not to remit. In the latter, no money remitted may be a consequence of random circumstances but generally the migrant is assumed to have an inclination (positive propensity) to remit ${ }^{22}$. This is the main reason why we face mixture of discrete and continuous distributions which makes use of traditional OLS unreliable (Mahuteau et al. 2010; Piracha and Saraogi 2012).

\footnotetext{
${ }^{21}$ This kind of information is also used for weighting of variables. In following analyses we will use the unweight data.

${ }^{22}$ In fact, Bettin et al. 2012 argue that the third category is also possible: those who want to remit but are unable to (e.g. because of high transfer costs). This case may be well taken in analyses of heterogeneous migrant groups but not necessarily in the analysis to follow. The same refers to argument raised by Mahuteau et al. 2010 and related to responses of remittances to changes in policy settings (not applicable in our case).
} 
Considering this methodological difficulty there are two main approaches applied:

1) If we assume that we face an one-stage simultaneous process it is possible to model the decision to remit and the amount of remittances simultaneously. Notwithstanding, censoring remains an issue, for the censored sample cannot be treated as a representative one and will produce biased estimates. One of commonly used solutions is the Tobit model - in this case the log-likelihood function has a form of traditional regression for uncensored observations and another one for the rest of distribution. Collier et al. (2011) argue that the Tobit model is applicable only when we face 'true censoring' (i.e. due to non-observability). This is not an issue in our case, particularly because we refer to relatively long time span (12 months) and temporary migration strategies, and thus can assume that all migrants who wanted to remit had an opportunity to do that. More important issue refers to the data generating process itself. Tobit explicitly assumes the same mechanism lying behind propensity to remit and the value of money remitted - in other words the same process generates both zeros and positive outcomes. In this paper, we argue that unless there is strong theoretical argument for rejecting such a possibility, we should not reject the Tobit model a'priori.

2) Assuming that remitting is a two-stage process one can utilize an explicit two-level model whereas first the decision to remit is modeled (e.g. using one of the categorical variable models as probit) and then the decision on the amount to be remitted is assessed (ordinary OLS can be used). In this case we are able to distinguish between regressors impacting the general propensity to remit and those factors responsible for a given value of money sent back home. Thus, the clear advantage of the two-part model is an opportunity to assess the determinants of probability and level of remittances separately (assuming that those mechanisms may differ). In this case, however, several options are available and there are serious concerns about decision to choose particular model. Piracha and Saraogi (2012) claim that the selection model (with Heckman correction) is better suited for the potential outcome while the two-part model suits better actual outcome. In case of the selection model exclusion restrictions are critical, i.e. inclusion in the selection equation such variables which are expected to impact only the selection process (and not the amount remitted). There are no clear theoretical arguments for such an assumption.

Last but not least, there are some concerns about endogeneity in the remittances models. In a recent paper Bettin at al. (2012) address the issues of endogeneity and (reverse) causality between remittances, income and consumption and apply several up-to date models (double-hurdle, Heckit selection model and Limited Information ML estimator) and point to endogeneity as potentially serious methodological problem demanding using particular econometric techniques (e.g. IV). The problem is following: we can assume than migrants who consider remitting more are more likely to work longer hours and also limit their consumption. However, those with debts in their home country can also be more likely to remit. Due to the fact that in our case we look at remitting behavior of relatively homogeneous migrant group originated from one country, facing similar costs of remitting money and representing similar consumption patterns endogeneity is not necessarily an issue but it will be assessed empirically in the future ${ }^{23}$.

Considering all the issues discussed above we argue that there are no clear theoretical arguments to decide a'priori whether one or two different processes govern the decision to remit and how much to remit. Consequently we will estimate three models for the sake of robustness check:

\footnotetext{
${ }^{23}$ Moreover, as shown in Bettin et al. 2012 estimates obtained through IV methods and 'traditional ones' were relatively close.
} 
1) Tobit model in a following form:

$$
R^{*}=\alpha+\beta_{1} X+\beta_{2} M+\beta_{3} N+\beta_{4} L+\beta_{5} H+\mu
$$

where $R^{*}$ relates to amount remitted, $X$ represents the vector of socio-demographics, $M$ relates to features of the migration process (including type of migration and time spent at destination), $N$ to the social network, $L$ to the labor market status (including income level) and $H$ captures several characteristics of the household (in Poland and in Ukraine), finally $\mu$ is normally distributed error term.

2) Two-part model, where remittances outcome is given by (Piracha and Saraogi 2012):

$$
R=d R^{*}
$$

with $\mathrm{d}=0$ for non-remitters and $\mathrm{d}=1$ for those who remit.

Participation equation is given by:

$$
R P=\alpha+\beta_{1} X+\beta_{2} M+\beta_{3} N+\beta_{4} L+\beta_{5} H+\vartheta
$$

And the level equation:

$$
R^{* *}=\max \left[0, R^{*}\right] \text { and } R^{*}=\alpha+\beta_{1} X+\beta_{2} M+\beta_{3} N+\beta_{4} L+\beta_{5} H+\mu
$$

Where all the regressors are the same as described above and $\vartheta$ and $\mu$ represent error terms (randomly distributed with bivariate normal distribution). Note that in our case we assume that two-part model includes the same set of regressors but they may differ (if necessary).

3) The selection model (Heckman correction) includes additionally a variable expected to capture the selectivity bias (Mill's ratio). In the first model a participation equation is estimated (similarly as in 2)) and then the Mill's ratio is derived on its basis to be included in the second equation (level equation). Additionally, it is assumed that unobservables from both equations have a bivariate distribution and are correlated. Importantly, in case of the selection model we use five exclusion restrictions (variables) assumed to impact exclusively the propensity to remit and not the amount transferred: three variables related to marital status - dummies for singles and divorced persons, and interaction term indicating divorced women - in all cases we expect that particular status represents particular stage in the life cycle and should impact the propensity to remit and not the amount of remittances; variable indicating permanent migrants (persons who declared plans to settle) - settled migrants are commonly described as those with weak ties to their countries of origin and thus weaker propensity to remit; and variable representing size of social network in Warsaw are - in this case, we assume that presence of strong networks significantly decreases risks related to migration and thus limits importance of the insurance motive, additionally, participation in networks can seriously impact chances to remit money in an unofficial way (but not the amount).

Dependent variables used in analyses to follow represent: 1) positive outcome of decision to remit (non zero value of remittances in previous 12 months - dummy variable; participation equation) and 2) amount of money remitted (or taken back personally) in previous 12 months (level equation) ${ }^{24}$. Set of independent variables reflects theoretical discussion on motives to remit as presented in the previous section. Generally, they can be divided into five major groups:

\footnotetext{
${ }^{24}$ As a robustness check relative amount of remittance (as compared to the income) as dependent variable was used - see below.
} 
Socio-demographic characteristics

Age and age squared are included to test for presence of inverse U-shaped age-profile of remittances (due to impact on income position and position in the life cycle). With respect to gender we include a variable indicating females and expect that women are less likely to remit and smaller amount of money which should be particularly the case in traditional, patriarchal societies with strong contractual arrangements within families. Married persons should be more likely to remit this is mostly due to higher probability of contractual arrangements and strong ties to household left behind. Theoretically contrary expectation should refer to divorced persons but in case of Ukrainian migration to Poland we are particularly interested in situation of divorced women (one of the peculiarities of this migration process) who are expected to remit more (migration as survival strategy). With respect to level of education, increase in this variable should result in higher propensity to remit (higher income, loan repayment), note however that there are also theoretical arguments against this expectation (e.g. well educated persons as less prone to social pressure). Additionally two interactions to control for effect of marital status in case of women (married and divorced) are added.

\section{Temporal patterns of migration}

Following the main hypothesis of this article we expect that type of migration / migration strategy impact seriously propensity to remit and level of remittances. Permanent migrants are expected to remit less (according to all theoretical motives). On contrary, temporary migrants may use remittances as a part of contractual arrangements and are more likely to remit due to altruistic motives. Additionally, in this case sending money back home can be seen as "investment" in future consumption. We include two indicators of temporary migration strategy: number of migrations since first arrival to Poland and frequency of visits to Ukraine. Additionally, we assume inverted Ushape profile of remittances with regard to time spent in Poland. Illegal status of migrants is expected to impact on propensity to remit in a positive way - this is mostly due to higher risks creating space for insurance motives.

\section{Social networks}

Member in the social network is expected to increase propensity to remit because of (theoretically) lower transfer costs and social pressure as a part of enforcement mechanism (note however that it also lowers the level of risk). In this case we refer to the number of persons known in the Warsaw area which unfortunately is only a weak proxy of social capital.

Labor market status

With regard to labor market status we refer particularly to the net annual income (in PLN) expected to increase propensity to migrate and amount remitted in a unequivocally positive way (according to most of the motives). Additionally we include two variables indicating employment in sectors particularly prone to risk and instability as a proxy of presence of self-insurance mechanisms: agriculture (more common in case of men) and household services (typical for women). 
Last but not least, we include a number of household characteristics. On the one hand, number of household members in Ukraine is a clear proxy of altruistic motives (and also contractual arrangements). On the other, number of household members in Poland and dependents present in Poland are clear sign of moving the life centre to the country of destination and weakening ties with former household (thus impacting propensity to remit in a negative way). Other migrants from the household (present in Poland) are usually treated as a factor impacting negatively on the propensity to remit due to altruistic motive.

Detailed description and summary statistics of all variables used along with expected signs and selected references includes Table $1 \mathrm{~A}$ in the Annex.

\section{RESULTS AND DISCUSSION}

In this section we present and discuss results of empirical analysis aimed at disentangling of remitting motives of Ukrainian immigrants in Poland. While doing that we will refer to outcomes of other similar studies, particularly those devoted to Central and Eastern European migrants - from Albania (Piracha and Saraogi 2011) and from Ukraine in the Czech Republic (Strielkowski et al. 2012).

\section{Evidence from descriptive analysis}

Before moving into multivariate analysis we start with discussion of basic descriptive statistics of variables describing remitting behavior of the group considered, Table 3.

From Table 3 it follows that there are only slight (and not significant) differences between males and females with respect to remitting propensity. On the contrary, males tend to remit more which may be to a large extent effect of the fact that - generally - they tend to earn relatively more. This outcome is similar to observations by Kupets (2012). In line with expectations, share of remitters is higher among non-permanent migrants, however even in case of those who reported settlement plans share of those who do remit is around 60 percent. This is a clear sign that Ukrainian migrants in Poland are, in general, relatively strongly attached to their country of origin. Non-permanent migrants remit also significantly higher amounts of money, however, again - amounts remitted by permanent migrants are also relatively high. 
Table 3. Remittances - basic descriptive statistics

\begin{tabular}{l|rr|rr}
\hline \multicolumn{1}{c|}{ Variable } & Mean & SD & Mean & SD \\
& \multicolumn{1}{c}{ Males } & & Females \\
Share of remitters & 0.697 & 0.461 & 0.669 & 0.471 \\
Value of remitted money (annually, PLN) & 5301.216 & 6486.972 & 4233.961 & 5310.922 \\
Share of money remitted for consumption purposes & 23.729 & 31.9627 & 21.489 & 31.104 \\
Share of money remitted for savings & 9.254 & 22.036 & 4.359 & 16.205 \\
Share of money remitted for investment purposes & 1.351 & 10.661 & 0.000 & 0.000 \\
$\mathbf{N}$ & $\mathbf{1 8 5}$ & - & $\mathbf{2 8 4}$ & - \\
\hline & Permanent migrants & Other migrants \\
Share of remitters & 0.586 & 0.496 & 0.697 & 0.460 \\
Value of remitted money (annually, PLN) & 3774.571 & 6332.039 & 4809.398 & 5720.111 \\
Share of money remitted for consumption purposes & 28.071 & 38.526 & 21.373 & 29.960 \\
Share of money remitted for savings & 5.571 & 21.102 & 6.416 & 18.457 \\
Share of money remitted for investment purposes & 0.000 & 0.000 & 0.626 & 7.280 \\
$\mathbf{N}$ & $\mathbf{7 0}$ & - & $\mathbf{3 9 9}$ & - \\
\hline
\end{tabular}

Source: Own elaboration based on the RDS/CMR/2012 data base.

Due to the fact that the questionnaire included explicit questions on share of remittances spent on particular purposes it is possible to refer to hypothesis proposed by Amuedo-Dorantes and Pozo (2006). The main group of respondents represent persons who claimed to spent the highest shares of money sent back for daily consumption. This is true in both cases of males and females ( 24 and 21 percent respectively) but also for permanent and other migrants (28 and 20 percent respectively). Interestingly, the highest average share was noted in case of those persons with settlement plans. It may suggest that consumption smoothing at origin is one of the major concerns of all migrants irrespective their future plans and this would suggest that migrants are primarily driven by altruisticlike motives. Other motives play much smaller role. This is particularly well taken in case of selfreported data on remittances spent on investment purposes. Shares in this category are negligible or very small (in case of males). This outcome is similar to many observations from less developed countries suggesting that 1 ) earnings abroad are not large enough to start productive investments at origin and 2) in the context of market failures typical for many sending countries we should not expect migrants and their families to behave like financial intermediaries (Kaczmarczyk 2005; Taylor 1999). Notwithstanding shares of money remitted as savings is much higher in case of males. Following Amuedo-Dorantes and Poso (2006) we thus can argue that self-interest and insurance motives are also clearly present in case of Ukrainians in Poland.

\section{Evidence from econometric analysis}

Table 4 presents outcomes of three econometric models estimated. First, the log likelihood for the Tobit model and the two-part model are very similar (slightly in favor of the two-part model which be used as point of reference in further analyses ${ }^{25}$ ). Now, critical question is whether participation process and process governing the amount of money remitted are significantly different in statistical terms. Model 3 (selection model) assumes that this is exactly the case. However, from the specification presented in Table 4 it follows that lambda (inverse Mills ratio) is not significant and, in turn, errors of two estimated models (participation and level) are not correlated in this case. Thus,

\footnotetext{
${ }^{25}$ Particularly that outcomes of both models are similar.
} 
we can accept results of the two-part model as not biased (it is not necessary to refer to exclusion restrictions) and will focused on this one in further discussion.

Table 4. Outcomes of the estimates: Tobit (1), two-part model (2) and selection model (3)

\begin{tabular}{|c|c|c|c|c|c|}
\hline & \multirow{2}{*}{$\frac{\text { Model } 1}{\text { Tobit }}$} & \multicolumn{2}{|c|}{ Model 2} & \multicolumn{2}{|c|}{ Model 3} \\
\hline & & Selection (probit) & Level (OLS) & Selection & Level \\
\hline \multirow[t]{2}{*}{ Age } & 261.970 & 0.059 & 58.756 & 0.059 & 135.462 \\
\hline & $(250.42)$ & $(0.06)$ & $(246.60)$ & $(0.06)$ & $(274.19)$ \\
\hline \multirow[t]{2}{*}{ Age_sq } & -3.167 & -0.000 & -1.431 & -0.000 & -2.232 \\
\hline & $(3.16)$ & $(0.00)$ & (3.09) & $(0.00)$ & $(3.37)$ \\
\hline \multirow[t]{2}{*}{ Female } & -214.319 & -0.194 & 1103.756 & -0.194 & -1262.807 \\
\hline & $(1378.88)$ & $(0.29)$ & $(1478.78)$ & $(0.29)$ & (1091.59) \\
\hline \multirow[t]{2}{*}{ Married } & $5037.073 * * *$ & 0.266 & $5123.838 * * *$ & 0.266 & \\
\hline & $(1252.24)$ & $(0.30)$ & (1217.02) & $(0.30)$ & \\
\hline \multirow[t]{2}{*}{ Divorced } & 2526.725 & 0.113 & 3152.681 & 0.113 & \\
\hline & $(1706.25)$ & $(0.37)$ & $(1706.26)$ & $(0.37)$ & \\
\hline \multirow[t]{2}{*}{ Fem*mar } & -3014.856 & 0.035 & $-4096.194 * *$ & 0.035 & \\
\hline & $(1545.23)$ & $(0.36)$ & $(1548.56)$ & $(0.36)$ & \\
\hline \multirow[t]{2}{*}{ Fem*div } & -1126.616 & 0.042 & -2547.087 & 0.042 & \\
\hline & (1975.39) & $(0.43)$ & $(2001.43)$ & $(0.43)$ & \\
\hline \multirow[t]{2}{*}{ Edu_level } & -410.826 & -0.119 & -84.127 & -0.119 & 224.375 \\
\hline & $(567.21)$ & $(0.13)$ & $(562.47)$ & $(0.13)$ & (595.77) \\
\hline \multirow[t]{2}{*}{ Per_m } & -212.183 & -0.026 & -21.705 & -0.026 & \\
\hline & $(1038.88)$ & $(0.24)$ & (1033.25) & $(0.24)$ & \\
\hline \multirow[t]{2}{*}{ Illegal } & -454.473 & -0.087 & -73.843 & -0.087 & 84.175 \\
\hline & (914.79) & $(0.22)$ & (901.09) & $(0.22)$ & (950.75) \\
\hline \multirow[t]{2}{*}{ No_m } & $525.480^{* * *}$ & $0.099 * *$ & $394.243 * *$ & $0.099 * *$ & 242.473 \\
\hline & (147.15) & $(0.04)$ & $(145.44)$ & $(0.04)$ & $(163.73)$ \\
\hline \multirow[t]{2}{*}{ Freq } & $3254.891^{* * *}$ & $0.408^{*}$ & $2255.509 * *$ & $0.408^{*}$ & 1940.368 \\
\hline & (825.87) & $(0.18)$ & $(848.62)$ & $(0.18)$ & (996.15) \\
\hline \multirow[t]{2}{*}{ Time } & $119.876^{*}$ & 0.019 & 84.946 & 0.019 & 32.822 \\
\hline & $(46.59)$ & $(0.01)$ & $(47.45)$ & $(0.01)$ & $(52.82)$ \\
\hline \multirow[t]{2}{*}{ Time_sq } & $-1.216^{* *}$ & $-0.000 *$ & -0.664 & $-0.000 *$ & -0.107 \\
\hline & $(0.43)$ & $(0.00)$ & $(0.45)$ & $(0.00)$ & $(0.54)$ \\
\hline \multirow[t]{2}{*}{ Soc_net } & 15.242 & $0.005^{*}$ & 2.571 & $0.005^{*}$ & \\
\hline & (8.59) & $(0.00)$ & $(8.20)$ & $(0.00)$ & \\
\hline \multirow[t]{2}{*}{ Net_ann } & $0.250 * * *$ & $0.000 * * *$ & $0.158 * * *$ & $0.000 * * *$ & $0.113^{*}$ \\
\hline & $(0.03)$ & $(0.00)$ & $(0.03)$ & $(0.00)$ & $(0.05)$ \\
\hline \multirow[t]{2}{*}{ S_agric } & 3223.091 & 0.643 & 2233.028 & 0.643 & 1429.152 \\
\hline & (1826.88) & $(0.46)$ & $(1755.30)$ & $(0.46)$ & (1856.94) \\
\hline \multirow[t]{2}{*}{ S_hhs } & 1281.550 & 0.142 & 867.983 & 0.142 & 657.673 \\
\hline & $(1021.85)$ & $(0.22)$ & $(1050.08)$ & $(0.22)$ & (1084.69) \\
\hline \multirow[t]{2}{*}{ Hh_pl } & -265.373 & 0.163 & $-850.052 *$ & 0.163 & $-1170.611^{* *}$ \\
\hline & $(421.38)$ & $(0.11)$ & (398.84) & $(0.11)$ & (439.02) \\
\hline \multirow[t]{2}{*}{ Hh_ukr } & $436.401^{*}$ & $0.195 * * *$ & 19.095 & $0.195^{* * *}$ & -141.085 \\
\hline & $(184.55)$ & $(0.05)$ & $(175.64)$ & $(0.05)$ & $(229.63)$ \\
\hline \multirow[t]{2}{*}{ Child_pl } & $-8337.425 * *$ & $-1.518 * *$ & -4921.386 & $-1.518^{* *}$ & -603.725 \\
\hline & (2592.60) & $(0.49)$ & $(2933.43)$ & $(0.49)$ & (3341.32) \\
\hline
\end{tabular}




\begin{tabular}{|c|c|c|c|c|c|}
\hline Hh_m & $\begin{array}{l}1145.554 \\
(1015.35)\end{array}$ & $\begin{array}{l}0.196 \\
(0.28)\end{array}$ & $\begin{array}{l}870.296 \\
(951.28)\end{array}$ & $\begin{array}{l}0.196 \\
(0.28)\end{array}$ & $\begin{array}{l}980.455 \\
(996.62)\end{array}$ \\
\hline Sigma & $\begin{array}{c}6098.313 * * * \\
(257.38)\end{array}$ & & & & \\
\hline Lambda & & & & $\begin{array}{l}-3836.713 \\
(2364.34)\end{array}$ & \\
\hline Constant & $\begin{array}{c}-16761.322 * * * \\
(4938.52) \\
\end{array}$ & $\begin{array}{c}-3.933 * * * \\
(1.18) \\
\end{array}$ & $\begin{array}{l}-3506.141 \\
(4907.98) \\
\end{array}$ & $\begin{array}{c}-3.933 * * * \\
(1.18) \\
\end{array}$ & $\begin{array}{l}2327.756 \\
(7607.82) \\
\end{array}$ \\
\hline$N$ & 431 & 431 & 303 & 431 & 303 \\
\hline Log likelihood & -3156.4669 & -190.9206 & -3015.5 & & \\
\hline Pseudo R2 & 0.0294 & 0.2718 & 0.1977 & & \\
\hline Prob > chi 2 & 0.0000 & 0.0000 & $0.0000^{a}$ & 0.0025 & \\
\hline
\end{tabular}

Source: Own elaboration based on the RDS/CMR/2012 data base.

First we focus on the participation equation showing factors responsible for remitting (or not). The first observation is related to type of migration and migration history of a given person. Apparently, both issues play a role in explaining propensity to remit. Persons with more extensive history of migration (measured by number of visits in Poland since their first arrival) and those who move between Ukraine and Poland more frequently (frequency of visits) are more likely to remit. Both variables are proxies of temporary migration schemes and we can argue that in case of temporary migrants remitting is an important part of contractual arrangements between the migrant and other family members. This observation supports our hypothesis saying that remittances from Poland to Ukraine are strongly correlated with temporary migration patterns. Variables describing time spent in Poland partially support the hypothesis as well show that time-profile of propensity to migrate has an inverted U-shape. On the contrary, presence of dependents in Poland has clearly negative impact on the likelihood of sending remittances - this is definitely the most important factor shaping remitting propensity. We argue that this variable captures the change in migration strategy and can be a clear sign of change in point of orientation or life centre of a given person (sending country vs. destination country). Interestingly, contrary to Strielkowski et al. (2012) there is no impact of gender on remitting propensity noted. This indicates significantly different migration patterns of those Ukrainians moving to the Czech Republic and Poland.

Propensity to remit increases with the number of household members staying in Ukraine. This is an argument supporting presence of altruistic motives. Interestingly - contrary to Piracha and Saraogi (2011) - there is no significant impact of other household members being active migrants. Moreover, sign would suggest rather positive than negative impact of this variable. This outcome could question altruistic motivation mentioned above or point to possible competition effects between migrants staying abroad (in line with Stark 2009). Notwithstanding, due to data limitations we are able to control for migrants staying in Poland only which suggests treating this outcome with utmost caution.

Propensity to remit is positively (and statistically significantly) correlated with net annual income. This is an interesting outcome for typically this variable is assumed to impact the amount remitted and not the likelihood (e.g. Strielkowski et al. 2012). Positive sign in this case may suggest that there 
is an entry level of income when remittances become feasible - e.g. due to transfer costs (if yes, this outcome would support claims by Bettin et al. 2012 suggesting distinguishing three and not two groups of would be remitters).

Importantly, contrary to predictions suggested by self-insurance models (Amuedo-Dorantes and Pozo 2006; Stark 2009) there is no impact of legal status on the propensity of remitting (nor on the amount sent back to Ukraine). We argue that in case of Ukrainian migrants in Poland illegal status does not necessarily create high risks for migrants (among others due to relatively high acceptance of illegal migrant workers) and thus should not be associated to presence of self-insurance mechanisms.

Finally, we find that propensity to remit increases with the size of social networks in Poland. Apparently, this outcome is controversial because we are not able to control for structure of the network (e.g. strong vs. weak ties) and capture only its purely quantitative characteristics. Notwithstanding, positive impact of migrant networks is contrary to Amuedo-Dorantes and Pozo (2006) but in line with many other authors including Piracha and Saraogi (2011). Positive impact of migrant networks is to be associated with its effects on easiness (and safety) of transfers. Additionally, being member of migrant networks gives to all kind of contractual arrangements more enforcement opportunities ("social control" over migrants - see among others Stark 2010).

As a second step we assess factors responsible for amount remitted (conditional on the fact of being remittances sender). Outcomes of participation and level equations are significantly different (in some cases changes in sings are noted) which suggests that both parts of the process - likelihood of sending remittances and decision about the amount to be remitted - are governed by distinctive mechanisms / processes.

In case of the level equation there is a clearly positive impact of marital status noted. Married persons are more likely to send more money home - this observation is in line with other studies on Ukrainian migrants (Kupets 2012; Strielkowski 2012) ${ }^{26}$. This outcome suggests, again, presence of altruistic motives with regard to those left behind. It is also supported by variable capturing divorced persons (significant at 0.06 level). Interestingly, this effect is even stronger for males (married) which, additionally, would indicate a process involving exchange motives (e.g. child or elderly care at origin). Contrary to expectations, there are no positive effects noted in case of divorced women.

Variables capturing time-profile of remittances are not significant (time is significant at 0.07 level) but show effects commonly reported in the literature. Inverted U-shape time profile of amount remittances sent is usually presented as a proxy of altruistic motives which tend to diminish with time spent abroad but can also represent effects associated with the loan repayment motive (Poirine 1997). Similarly, there is negative but also not significant effect of education (contrary among others to Piracha and Saraogi 2011). This is not surprising considering modes of participation of Ukrainian immigrants in the Polish labor market who are employed primarily in secondary sectors with low returns on skills. The case analyzed presents thus an interesting comment on the long-lasting discussion on relationship between level of education and remittances. In case when there is barely return to education possible most of effects suggested in literature are highly questionable.

\footnotetext{
${ }^{26}$ Note that this outcome question the decision to put this variable to selection equation only (in case of Heckman model). However, inclusion of variables related to marital status in the level equation does not change results significantly.
} 
Similarly to the participation equation, variables serving as proxies of temporary migration schemes prove to have an important impact on value of remittances. Temporary migrants with relatively longer migration histories remit clearly more. This is also indicated by negative sign of the variable indicating persons with settlement plans. In case of the level equation presence of dependents in Poland is not as strong indicator as noted in the previous case (variable is significant only at 0.09 level). With regard to the amount sent back is significantly negatively impacted by the size of household in Poland. Again, this may suggest that along with process of settlement both propensity to remit as well as amount remitted tend to decline. This observation would support both altruistic motives as well as self-interest ones. Importantly, while women have considerably lower propensity to remit, ceteris paribus value of their remittances is higher than in case of men. This would support predictions resulting from the altruistic model.

Clearly, net annual income is the most important variable explaining value of remittances sent by Ukrainian immigrants in Poland. This outcome is in line with most of the analyses reported in the literature. ${ }^{27}$ As a robustness check an additional set of models has been estimated whereas share of remittances in (net) annual income was used as dependent variable, see Table $2 \mathrm{~A}$ in the Annex. Outcomes of the second set of models are strictly consistent with estimates discussed above at the selection level. The only difference refers to level equations: apparently when relative value of remittances is considered the net income ceases to be significant explanatory variable (which is intuitive), instead the variance of dependent variable is to be explained by marital status (particularly being married), gender, migration patterns and presence of other household members in Poland.

To sum up, similarly to other pieces of research analysis presented does not allow to fully disentangle all possible factors responsible for sending remittances. There are clear indicators of altruistic motives - ties to the household abroad, level of income, return intentions but without controlling for income or assets of the household at origin it is difficult to differentiate those effects from those related to self-interest motives. On the other hand, we provide a number of arguments suggesting presence of contractual arrangements between migrants and their kin. This is particularly well taken in case of temporary migration patterns. For temporary migrants remittances are not only part of inter-temporal exchange mechanism. They can be also interpreted in the context of life cycle hypothesis as suggested by Dustman and Mestres (2010) - in this case money remitted home can be interpreted as "investment" meant to improve migrants' position upon return. From this perspective it is more easily to understand the mixed nature of remitting motives: sending money back home by temporary migrants may be treated as a manifestation of family support (or pure altruistic behavior) but also as simple savings or investment for future consumption at home.

\section{CONCLUDING REMARKS}

Remittances are among the most often analyzed aspects of international mobility of persons. This is due to its importance for both countries and people involved. In the latter case, money sent back home can be critically important for economic survival. While looking at recent Ukrainian immigrants

\footnotetext{
${ }^{27}$ Unfortunately, we are not able to control for the income of sending household to distinguish between altruistic motives and those related to self-interest or contractual arrangements.
} 
in Poland we aimed at assessment of patterns of remittances sent by Ukrainian migrants, identification of the main motives to remit and, generally, at better understanding of remitting behavior.

Due to the fact that we focused on one particular process it would be difficult to present the results in universal or general terms, but unequivocally analysis provided sheds some light on mechanisms behind remittances sent by Ukrainian immigrants residing in Poland. Most of the empirical outcomes are to be interpreted in the context of the very nature of migration process: there are clear signs that Ukrainian migrants in Poland are, in general, strongly attached to their country of origin. This is one of the reasons why even those persons who declare willingness to settle, still tend to remit. In their case altruistic motives are probably the most important ones - it suggests that consumption smoothing at origin is one of the major concerns of all migrants irrespective their future plans. Similarly to other known studies, disentanglement of possible remitting motives turned out to be a very difficult task. There are clear indicators of altruistic motives - ties to the household abroad, level of income, return intentions. The problem is, however, that without controlling for income or assets of the household at origin (which was not possible) it is difficult to differentiate those effects from those related to self-interest motives. On the other hand, we provide a number of arguments suggesting presence of contractual arrangements between migrants and their heirs.

The last argument - as well as those related to self-interest and insurance motives also clearly present in case of Ukrainians in Poland - seems to be particularly well taken in case of temporary migration schemes. There are many signs of presence of contractual arrangements between the migrant and other family members. Temporary migrants, particularly those with long migration records and those with life centers (still) located in Ukraine, are more prone to remit and remit considerably more. However, we argue that for temporary migrants remittances are not only part of inter-temporal exchange mechanism. Additional reason why they are more prone to remit is that in their case money remitted home can be interpreted as "investment" meant to improve migrants' position upon return, clearly understandable when we conclude that recent migrants' incomes are much higher than expected future earnings in country of origin. From this perspective it is more easily to understand the mixed nature of remitting motives: sending money back home by temporary migrants may be treated as a manifestation of family support (or pure altruistic behavior) but also as simple savings or investment for future consumption at home.

This outcome is important from the policy perspective. We can argue that if temporary migration is associated with higher level of remittances migration policies aiming at increasing level of remittances world-wide should promote and encourage predominantly temporary and circular forms of mobility. In presence of well-developed migrant networks economic strategies involving migration and remittances can be efficient in consumption smoothing and investment support in sending countries. 


\section{REFERENCES}

Adams, Richard H. Jr. 2011. Evaluating the Economic Impact of International Remittances On Developing Countries Using Household Surveys: A Literature Review. The Journal of Development Studies 47(6): 809-828.

Adams, Richard. 1991. The economic uses and impact of international remittances in rural Egypt. Economic Development and Cultural Change 39: 695-722.

Agarwal, Reena and Andrew W. Horowitz. 2002. Are International Remittances Altruism or Insurance? Evidence from Guyana Using Multiple-Migrant Households. World Development 30(11): 2033-2044.

Amuedo-Dorantes, Catalina and Susan Pozo. 2006. Remittances as insurance: evidence from Mexican immigrants. Journal of Population Economics 19: 227-254.

Amuedo-Dorantes, Catalina and Susan Pozo. 2011. Remittances and Income Smoothing. American Economic Review: Papers \& Proceedings 101(3): 582-587.

Amuedo-Dorantes, Catalina and Susan Pozo. 2012. Remittances and Portfolio Values: An Inquiry Using Spanish Immigrants from Africa, Europe and the Americas. IZA Discussion Paper 6622.

Aparicio, Ainhoa. 2011. Network Effects on Migrants' Remittances. IZA Discussion Paper No. 5657.

Arun, Thankom and Hulya Ulku. 2011. Determinants of Remittances: The Case of the South Asian Community in Manchester. The Journal of Development Studies 47(6): 894-912.

Banerjee, Bisvajit. 1984. The probability, size, and uses of remittances from urban to rural areas in India. Journal of Development Economics 16: 293-311.

Bettin, Giulia, Lucchetti, Riccardo and Alberto Zazzaro. 2012. Endogeneity and sample selection in a model for remittances. Journal of Development Economics 99: 370-384.

Bollard, Albert, McKenzie, David, Morten, Melanie and Hillel Rapoport. 2009. Remittances and the Brain Drain Revisited: The Microdata Show That More Educated Migrants Remit More. IZA DP No. 4534.

Brown, P.C. Richard. 1997. Estimating Remittance Functions for Pacific Island Migrants. World Development 25(4): 613-626.

Brown, Richard P.C. and Bernard Poirine. 2005. A Model of Migrants' Remittances with Human Capital Investment and Interfamilial Transfers. International Migration Review 39(2): 407-438.

Cassarino, Jean-Pierre. 2004. Theorising Return Migration: a revisited conceptual approach to return migrants. EUI Working Papers RSCAS 2004/02.

Catrinescu, Natalia, Leon-Ledesma, Miguel, Piracha, Matloob and Bryce Quillin. 2006. Remittances, Institutions and Economic Growth. IZA DP No. 2139.

Collier, William, Piracha, Matloob and Teresa Randazzo. Network Effects on Migrants' Remittances. IZA Discussion Paper No. 6091.

De Haas, Hein. 2005. International migration, remittances and development: myths and facts, Third World Quarterly 26(8): 1269-1284. 
de la Briere, Benedicte, Sadoulet, Elisabeth, de Janvry, Alain and Sylvie Lambert. 2002. The roles of destination, gender, and household composition in explaining remittances: an analysis for the Dominican Sierra. Journal of Development Economics 68: 309-328.

Docquier, Frédéric, Rapoport, Hillel and Sara Salomone. 2011. Remittances, Migrants' Education and Immigration Policy: Theory and Evidence from Bilateral Data. IZA Discussion Paper No. 6104.

Dustmann, Christian and Josep Mestres. 2010. Remittances and temporary migration. Journal of Development Economics 92: 62-70.

Faini, Riccardo. 2007. Remittances and the Brian Drain: Do More skilled Migrants Remit More? The World Bank Economic Review 21(2): 177-191.

Funkhouser, Edward. 1995. Remittances from International Migration: A Comparison of El Salvador and Nicaragua. The Review of Economics and Statistics 77(1): 137-146.

Hagen-Zanker, Jessica and Melissa Siegel. 2007. The determinants of remittances: A review of the literature. MGSoG Working Paper 003/2007.

Hanson, Gerorge. 2006. Illegal migration from Mexico to the United States. National Bureau of Economic Research working paper 12141.

Havolli, Sokol. 2009. Determinants of remittances: The case of Kosovo. Central Bank of the Republic of Kosovo Working Paper No. 3.

Hoddinott, John. 1992. Modeling remittance flows in Kenya. Journal of African Economies 1 (2): 206232.

Hoddinott, John. 1994. A model of migration and remittances applied to western Kenya. Oxford Economic Papers 46(3): 459-476.

Holst, Elka and Mechtschild Schrooten. 2006. Migration and Money - What Determines Remittances? Evidence from Germany. DIW Discussion Papers 566.

Holst, Elke, Schäfer, Andrea and Mechthild Schrooten. 2012. Gender and Remittances: Evidence from Germany. Feminist Economics 18(2): 201-229.

Kaczmarczyk, Paweł. 2005. Migracje zarobkowe Polaków w dobie przemian. Warsaw: WUW.

Karapetyan, Lili and Liana Harutyunyan. 2013. The Development and Side Effects of Remittances in CIS countries: the Case of Armenia. CARIM-East Research Report 2013/24. Florence: EUI.

Knowles, Richard and James C. Anker. 1981. An analysis of income transfers in a developing country: The case of Kenya. Journal of Development Economics 8: 205-226.

Kupets, Olga. 2012. The Development and Side Effects of Remittances in CIS countries: the Case of Ukraine. CARIM-East Research Report 2012/02. Florence: EUI.

Lauby, Jennifer L. and Oded Stark. 1988. Individual migration as a family strategy: young women in the Philippines. Population Studies 42: 473-486.

Liang, Zai, Li, Jiejin and Zhongdong Ma. 2013. Migration and Remittances. Asian Population Studies, DOI:10.1080/17441730.2013.785721. 
Lucas, Rober E.B. and Oded Stark. 1985. Motivations to remit: Evidence from Botswana. Journal of Political Economy 93(5): 901-918.

Mahuteau, Stephane, Piracha, Matloob and Massimiliano Tani. 2010. Selection Policy and Immigrants' Remittance Behaviour. University of Kent, School of Economics Discussion Papers KDPE 1003.

Markova Eugenia and Barry Reilly. 2007. Bulgarian Migrant Remittances and Legal status: Some Micro-Level Evidence from Madrid. South-Eastern Europe Journal of Economics 1: 55-69.

Mazzucato, Valentina. 2009. Informal Insurance Arrangements in Ghanaian Migrants' Transnational Networks: The Role of Reverse Remittances and Geographic Proximity. World Development 37(6): 1105-1115.

Merkle, Lucia and Klaus F. Zimmermann. 1992. Savings, remittances, and return migration. Economics Letters 38: 77-81.

Nikas, Christos and Grigoris Baklavas. 2009. Savings and remitting attitudes of Albanian emigrants an exploratory data analysis. Southeast European and Black Sea Studies 9(4): 481-495.

Nimi, Yoko, Ozden, Schiff and Maurice Schiff. 2008. Remittances and the Brain Drain: Skilled Migrants Do Remit Less. IZA DP No. 3393.

Okonkwo Osili, Una. 2007. Remittances and savings from international migration: Theory and evidence using a matched sample. Journal of Development Economics 83: 446-465.

Piracha, Matloob and Amrita Saraogi. 2011. Motivations for Remittances: Evidence from Moldova. IZA Discussion Paper No. 5467.

Piracha, Matloob and Yu Zhu. 2012. Precautionary Savings by Natives and Immigrants in Germany. Applied Economics 44(21): 2767-2776.

Poirine, Bernard. 1997. A theory of remittances as an implicit family loan arrangement. World Development 25: 589-611.

Rahman, Md Mizanur and Lian Kwen Fee. 2012. Towards a Sociology of Migrant Remittances in Asia: Conceptual and Methodological Challenges, Journal of Ethnic and Migration Studies 38(4): 689-706.

Rapoport, Hillel and Frederic Docquier. 2006. The economics of migrants' remittances. In S.-C. Kolm and J. Mercier Ythier, eds. Handbook of the Economics of Giving, Altruism and Reciprocity, North Holland, Chapter 17, pp. 1135-98.

Sana, Mariano and Douglas S. Massey. 2005. Household Composition, Family Migration and Community Context: Migrant Remittances in Four Countries. Social Science Quarterly 86(2): 509528.

Siegel, Melissa. 2010. Money and Mobility: Migration and Remittances, MGSoG Dissertation Series.

Soltero, Jose. 2009. Determinants of Remittances to Mexico From Mexican-Born Immigrants in Chicago. Journal of Poverty 13(3): 319-330.

Stark, Oded, Edward J. Taylor and Shlomo Yitzkaki. 1986. Remittances and Inequality. The Economic Journal 96: 722-740. 
Stark, Oded. 1980. On the role of rural-urban remittances in rural development. Journal of Development Studies 16: 369-374.

Stark, Oded. 1983. Towards a theory of remittances in LDCs. Harvard Institute of Economic Research discussion paper 971.

Stark, Oded. 2010. Reasons for remitting. World Economics 10(3): 147-157.

Stratan, Alexandru, Chistruga, Marcel, Clipa, Victoria, Fala, Alexandru and Viorica Septelici. 2013. The Development and Side Effects of Remittances in CIS countries: the Case of Republic of Moldova. CARIM-East Research Report 2013/2. Florence: EUI.

Strielkowski, Wadim, Glazar, Ondrej and Blanka Weyskrabova. 2012. Migration and remittances in the CEECs: a case study of Ukrainian labour migrants in the Czech Republic. IES Working Paper: $19 / 2012$.

Taylor, Edward. 1999. The new economics of labour migration and the role of remittances in the migration process. International Migration 37(1): 63-88.

Ullah, K.M. Ahsan. 2011. Dynamics of remittance practices and development: Bangladeshi overseas migrants. Development in Practice 21(8): 1153-1167.

Vullnetari, Julie and Russell King. 2011. Gendering remittances in Albania: a human and social development perspective. Gender \& Development 19(1): 39-51. 
ANNEX

Table 1A. Description of variables and summary statistics

\begin{tabular}{|c|c|c|c|c|c|c|}
\hline Variables & Definition & $\begin{array}{c}\text { Selection (s) / } \\
\text { level (I) equation }\end{array}$ & $\begin{array}{l}\text { Expected } \\
\text { sign }\end{array}$ & References & Mean & SD \\
\hline \multicolumn{7}{|c|}{ Dependent variables } \\
\hline $\begin{array}{l}\text { Sent remittances } \\
\text { (rem_sent) }\end{array}$ & $\begin{array}{l}\text { Dummy variable; } 1 \text { if sent } \\
\text { remittances back to Ukraine } \\
\text { during last } 12 \text { months }\end{array}$ & $\mathrm{s}$ & n.a. & Most of empirical applications & 0.680 & 0.467 \\
\hline $\begin{array}{l}\text { Amount remitted } \\
\text { (rem_level) }\end{array}$ & $\begin{array}{l}\text { Value of remittances sent in } \\
\text { last } 12 \text { months }\end{array}$ & $\mathrm{I}$ & n.a. & Most of empirical applications & 4654.947 & 5820.083 \\
\hline $\begin{array}{l}\text { Remittances } \\
\text { relative to income } \\
\text { (rem_income) }\end{array}$ & $\begin{array}{l}\text { Share of remittances in annual } \\
\text { income (net) }\end{array}$ & 1 & n.a. & n.a. & 0.168 & 0.188 \\
\hline \multicolumn{7}{|c|}{ Independent variables } \\
\hline Age (age_m) & Age of respondent & $\mathrm{s} / \mathrm{l}$ & + & $\begin{array}{l}\text { Holst and Schrotten 1996; Merkle } \\
\text { and Zimmernann 1992; Stark 2009; } \\
\text { Lauby and Stark 1988; Piracha and } \\
\text { Saraogi } 2011\end{array}$ & 37.763 & 10.799 \\
\hline $\operatorname{Age}^{2}$ (age_sq) & Age squared & $\mathrm{s} / \mathrm{l}$ & - & $\begin{array}{l}\text { Holst and Schrotten 1996; Merkle } \\
\text { and Zimmernann 1992; Strielkowski } \\
\text { et al. } 2012\end{array}$ & 1542.437 & 824.2748 \\
\hline Female & Yes = 1 (gender dummy) & $\mathrm{s} / \mathrm{l}$ & - & $\begin{array}{l}\text { Funkhouser 1995; Holst and } \\
\text { Schrotten 1996; Konica 2006; Lauby } \\
\text { and Stark 1988; Piracha and Saraogi } \\
2011\end{array}$ & 0.394 & 0.489 \\
\hline Married & Yes = 1 for married persons & $\mathrm{s}$ & + & $\begin{array}{l}\text { Durand et al. 2006; Holst and } \\
\text { Schrotten 1996; Merkle and } \\
\text { Zimmernann 1992; Lauby and Stark } \\
1988\end{array}$ & 0.418 & 0.494 \\
\hline $\begin{array}{l}\text { Divorced / } \\
\text { widowed (div) }\end{array}$ & $\begin{array}{l}\text { Yes = } 1 \text { for divorced or } \\
\text { widowed persons }\end{array}$ & $\mathrm{s}$ & + & $\begin{array}{l}\text { Durand et al. 2006; Holst and } \\
\text { Schrotten 1996; Merkle and } \\
\text { Zimmernann 1992; Lauby and Stark } \\
1988\end{array}$ & 0.258 & 0.438 \\
\hline $\begin{array}{l}\text { Level of education } \\
\text { (edu_level) }\end{array}$ & $\begin{array}{l}\text { Primary education }=1, \\
\text { secondary education=2, } \\
\text { tertiary education }=3\end{array}$ & $\mathrm{~s} / \mathrm{l}$ & + & $\begin{array}{l}\text { Piracha and Saraogi 2011; Stark } \\
\text { 1999; Durand et al. 2006; Holst and } \\
\text { Schrotten 1996; Merkle and } \\
\text { Zimmernann 1992; Niimi et al. 2006; } \\
\text { Docquier et al. } 2011\end{array}$ & 2.348 & 0.596 \\
\hline $\begin{array}{l}\text { Permanent } \\
\text { (per_m) }\end{array}$ & Persons with plans to settle & $\mathrm{s}$ & - & Stark 2009; Piracha and Saraogi 2011 & 0.149 & 0.357 \\
\hline $\begin{array}{l}\text { Legal status } \\
\text { (illegal) }\end{array}$ & $\begin{array}{l}\text { Illegal = } 1 \text { if person is staying in } \\
\text { Poland illegally (without } \\
\text { necessary documents) }\end{array}$ & $\mathrm{s} / \mathrm{l}$ & + & $\begin{array}{l}\text { Hagen Zanker and Siegel 2007; Pozo } \\
\text { 2005; Hanson 2006, Amuedo- } \\
\text { Dorantes and Pozo } 2006\end{array}$ & 0.200 & 0.401 \\
\hline $\begin{array}{l}\text { Number of } \\
\text { migrations } \\
\text { (no_m) }\end{array}$ & $\begin{array}{l}\text { Number of trips since the first } \\
\text { arrival }\end{array}$ & $\mathrm{s} / \mathrm{l}$ & + & $\begin{array}{l}\text { Dustman and Mestres 2010; Holst } \\
\text { and Schrooten 2006; Collier et al. } \\
2011\end{array}$ & 3.878 & 2.750 \\
\hline
\end{tabular}




\begin{tabular}{|c|c|c|c|c|c|c|}
\hline $\begin{array}{l}\text { Frequency of } \\
\text { visits (freq) }\end{array}$ & $\begin{array}{l}\text { Freq }=1 \text { for persons reporting } \\
\text { visits home at least once per } 6 \\
\text { months }\end{array}$ & $s / l$ & + & $\begin{array}{l}\text { Dustman and Mestres 2010; Holst } \\
\text { and Schrooten 2006; Collier } \text { et al. } \\
2011\end{array}$ & 0.725 & 0.447 \\
\hline $\begin{array}{l}\text { Time spent in PL } \\
\text { (time) }\end{array}$ & $\begin{array}{l}\text { Number of months spent in } \\
\text { Poland (recent trip) }\end{array}$ & $s / l$ & + & $\begin{array}{l}\text { Banerjee 1984; Conica 2006; Stark } \\
\text { 2009; Hagen Zanker and Siegel } 2007\end{array}$ & 11.859 & 22.274 \\
\hline $\begin{array}{l}\text { Time spent in } \mathrm{PL}^{2} \\
\text { (time_sq) }\end{array}$ & Time spent in Poland squared & $\mathrm{s} / \mathrm{l}$ & - & $\begin{array}{l}\text { Banerjee 1984; Conica 2006; Stark } \\
\text { 2009; Hagen Zanker and Siegel } 2007\end{array}$ & 635.737 & 3759.580 \\
\hline $\begin{array}{l}\text { Social networks } \\
\text { (soc_net) }\end{array}$ & $\begin{array}{l}\text { Number of persons known in } \\
\text { Warsaw area }\end{array}$ & $\mathrm{s}$ & + & Stark 2009; Piracha and Saraogi 2011 & 30.188 & 36.277 \\
\hline $\begin{array}{l}\text { Net income } \\
\text { (net_ann) }\end{array}$ & Annual net income (in PLN) & $\mathrm{s} / \mathrm{l}$ & + & $\begin{array}{l}\text { Stark 2009; Hagen Zanker and Siegel } \\
\text { 2007; Banerjee 1984; Funkhouser } \\
\text { 1995; Holst and Schrotten } 2006\end{array}$ & 27412.060 & 10044.210 \\
\hline $\begin{array}{l}\text { Agriculture } \\
\text { (s_agric) }\end{array}$ & $\begin{array}{l}\text { S_agric }=1 \text { for persons } \\
\text { employed in agriculture } \\
\text { (dummy) }\end{array}$ & $\mathrm{s} / \mathrm{l}$ & + & $\begin{array}{l}\text { Stark 2009, Amuedo-Dorantes and } \\
\text { Pozo } 2006\end{array}$ & 0.0277 & 0.164 \\
\hline $\begin{array}{l}\text { Personal services } \\
\text { (s_hhs) }\end{array}$ & $\begin{array}{l}\text { S_hhs }=1 \text { for persons employed } \\
\text { in household services (dummy) }\end{array}$ & $\mathrm{s} / \mathrm{l}$ & + & $\begin{array}{l}\text { Stark 2009, Amuedo-Dorantes and } \\
\text { Pozo } 2006\end{array}$ & 0.431 & 0.496 \\
\hline Size of HH (hh_pl) & $\begin{array}{l}\text { Number of household } \\
\text { members present in Poland }\end{array}$ & $\mathrm{s} / \mathrm{I}$ & - & Piracha and Saraogi 2011 & 1.480 & 0.926 \\
\hline $\begin{array}{l}\text { Size of the } \mathrm{HH} \text { in } \\
\text { country of origin } \\
\text { (hh_ukr) }\end{array}$ & $\begin{array}{l}\text { Number of household } \\
\text { members in the sending } \\
\text { country }\end{array}$ & $\mathrm{s} / \mathrm{l}$ & + & Piracha and Saraogi 2011 & 3.443 & 1.799 \\
\hline $\begin{array}{l}\text { Children abroad } \\
\text { (child_PL) }\end{array}$ & $\begin{array}{l}\text { Dependents present in Poland } \\
\text { (dummy) }\end{array}$ & $\mathrm{s} / \mathrm{I}$ & + & Piracha and Saraogi 2011 & 0.024 & 0.152 \\
\hline $\begin{array}{l}\text { Other migrants } \\
\text { (hh_m) }\end{array}$ & $\begin{array}{l}\text { Other members of the } \\
\text { household present as migrants } \\
\text { in Poland (dummy) }\end{array}$ & $\mathrm{s}$ & $-1+$ & $\begin{array}{l}\text { Stark 2009; Poirine 1997; Piracha } \\
\text { and Saraogi } 2011\end{array}$ & 0.181 & 0.386 \\
\hline
\end{tabular}

Source: Own elaboration. 
Table 2A. Remittances relative to income as dependent variable: Tobit (1), two-part model (2) and selection model (3)

\begin{tabular}{|c|c|c|c|c|c|}
\hline & \multirow{2}{*}{$\frac{\text { Model } 1}{\text { Tobit }}$} & \multicolumn{2}{|c|}{ Model 2} & \multicolumn{2}{|c|}{ Model 3} \\
\hline & & Selection (probit) & Level (OLS) & Selection & Level \\
\hline \multirow[t]{2}{*}{ Age } & 0.007 & 0.059 & -0.000386 & 0.059 & 0.004 \\
\hline & $(0.82)$ & $(0.99)$ & $(-0.05)$ & (0.99) & $(0.51)$ \\
\hline \multirow[t]{2}{*}{ Age_sq } & -0.0000719 & -0.000448 & -0.00000935 & -0.000 & -0.000 \\
\hline & $(-0.67)$ & $(-0.59)$ & $(-0.09)$ & $(-0.59)$ & $(-0.54)$ \\
\hline \multirow[t]{2}{*}{ Female } & -0.031 & -0.194 & 0.0101 & -0.194 & -0.051 \\
\hline & $(-0.65)$ & $(-0.68)$ & $(0.21)$ & $(-0.68)$ & $(-1.48)$ \\
\hline \multirow[t]{2}{*}{ Married } & $0.143 * * *$ & 0.266 & $0.143 * * *$ & 0.266 & \\
\hline & (3.32) & $(0.89)$ & (3.60) & $(0.89)$ & \\
\hline \multirow[t]{2}{*}{ Divorced } & 0.0803 & 0.113 & 0.0892 & 0.113 & \\
\hline & $(1.37)$ & $(0.30)$ & $(1.60)$ & $(0.30)$ & \\
\hline \multirow[t]{2}{*}{ Fem*mar } & -0.066 & 0.035 & $-0.106^{*}$ & 0.0351 & \\
\hline & $(-1.26)$ & $(0.10)$ & $(-2.11)$ & $(0.10)$ & \\
\hline \multirow[t]{2}{*}{ Fem*div } & -0.016 & 0.042 & -0.054 & 0.042 & \\
\hline & $(-0.23)$ & $(0.10)$ & $(-0.83)$ & $(0.10)$ & \\
\hline \multirow[t]{2}{*}{ Edu_level } & -0.009 & -0.119 & 0.006 & -0.119 & 0.013 \\
\hline & $(-0.46)$ & $(-0.91)$ & $(0.34)$ & $(-0.91)$ & $(0.68)$ \\
\hline \multirow[t]{2}{*}{ Per_m } & -0.001 & -0.026 & 0.012 & -0.0263 & \\
\hline & $(-0.03)$ & $(-0.11)$ & $(0.36)$ & $(-0.11)$ & \\
\hline \multirow[t]{2}{*}{ Illegal } & -0.023 & -0.087 & -0.0191 & -0.087 & -0.018 \\
\hline & $(-0.75)$ & $(-0.40)$ & $(-0.65)$ & $(-0.40)$ & $(-0.61)$ \\
\hline \multirow[t]{2}{*}{ No_m } & $0.017^{* * *}$ & $0.099 * *$ & $0.013 * *$ & $0.099 * *$ & $0.0102 *$ \\
\hline & $(3.45)$ & $(2.73)$ & $(2.81)$ & $(2.73)$ & $(2.00)$ \\
\hline \multirow[t]{2}{*}{ Freq } & $0.108 * * *$ & $0.408^{*}$ & $0.066^{*}$ & $0.408^{*}$ & $0.066^{*}$ \\
\hline & (3.83) & $(2.27)$ & $(2.40)$ & $(2.27)$ & $(2.12)$ \\
\hline \multirow[t]{2}{*}{ Time } & $0.004 *$ & 0.019 & 0.003 & 0.019 & 0.002 \\
\hline & $(2.51)$ & $(1.81)$ & $(1.90)$ & $(1.81)$ & $(1.12)$ \\
\hline \multirow[t]{2}{*}{ Time_sq } & $-0.0000414 * *$ & $-0.000236^{*}$ & -0.000 & $-0.000 *$ & -0.000 \\
\hline & $(-2.85)$ & $(-2.51)$ & $(-1.65)$ & $(-2.51)$ & $(-0.79)$ \\
\hline \multirow[t]{2}{*}{ Soc_net } & 0.000 & $0.00466 *$ & -0.000 & $0.004 *$ & \\
\hline & (1.69) & $(2.01)$ & $(-0.07)$ & $(2.01)$ & \\
\hline \multirow[t]{2}{*}{ Net_ann } & $0.00000374 * *$ & $0.0000531^{* * *}$ & -0.00000111 & $0.0000531^{* * *}$ & -0.000 \\
\hline & $(3.24)$ & $(5.48)$ & $(-1.01)$ & $(5.48)$ & $(-1.24)$ \\
\hline \multirow[t]{2}{*}{ S_agric } & 0.088 & 0.643 & 0.048 & 0.643 & 0.033 \\
\hline & $(1.41)$ & $(1.40)$ & $(0.84)$ & $(1.40)$ & $(0.57)$ \\
\hline \multirow[t]{2}{*}{ S_hhs } & 0.056 & 0.142 & 0.051 & 0.142 & 0.047 \\
\hline & $(1.62)$ & $(0.64)$ & (1.49) & $(0.64)$ & $(1.38)$ \\
\hline \multirow[t]{2}{*}{ Hh_pl } & -0.010 & 0.163 & $-0.030^{*}$ & 0.163 & $-0.037 * *$ \\
\hline & $(-0.66)$ & $(1.52)$ & $(-2.34)$ & $(1.52)$ & $(-2.72)$ \\
\hline \multirow[t]{2}{*}{ Hh_ukr } & $0.017^{* *}$ & $0.195^{* * *}$ & 0.001 & $0.195^{* * *}$ & -0.001 \\
\hline & $(2.68)$ & (3.79) & $(0.23)$ & (3.79) & $(-0.12)$ \\
\hline Child_pl & $-0.258 * *$ & $-1.518^{* *}$ & -0.160 & $-1.518 * *$ & -0.068 \\
\hline & $(-2.94)$ & $(-3.10)$ & $(-1.68)$ & $(-3.10)$ & $(-0.64)$ \\
\hline Hh_m & 0.033 & 0.196 & 0.021 & 0.196 & 0.026 \\
\hline & $(0.94)$ & $(0.71)$ & $(0.67)$ & $(0.71)$ & $(0.84)$ \\
\hline
\end{tabular}




\begin{tabular}{|c|c|c|c|c|c|}
\hline Sigma & $\begin{array}{c}0.209 * * * \\
(23.48)\end{array}$ & & & & \\
\hline Lambda & & & & $\begin{array}{l}-0.062 \\
(0.07)\end{array}$ & \\
\hline Constant & $\begin{array}{c}-0.417^{*} \\
(-2.49)\end{array}$ & $\begin{array}{c}-3.933 * * * \\
(-3.32)\end{array}$ & $\begin{array}{l}0.108 \\
(0.68)\end{array}$ & $\begin{array}{c}-3.933 * * * \\
(-3.32)\end{array}$ & $\begin{array}{l}0.157 \\
(0.66)\end{array}$ \\
\hline$N$ & 431 & 431 & 303 & 431 & 303 \\
\hline Log likelihood & -46.9945 & -190.9206 & 115.0795 & & \\
\hline Pseudo R2 & 0.6130 & 0.2718 & 0.1143 & & \\
\hline Prob > chi2 & 0.0000 & 0.0000 & 0.0001 & 0.0122 & \\
\hline
\end{tabular}

Source: Own elaboration based on the RDS/CMR/2012 data base. 